San Jose State University

SJSU ScholarWorks

Master's Theses

Master's Theses and Graduate Research

1994

\title{
The relationship between water and fuelwood availability and women's tasks in three rural communities in Oaxaca, Mexico
}

Mindy Fisher

San Jose State University

Follow this and additional works at: https://scholarworks.sjsu.edu/etd_theses

\section{Recommended Citation}

Fisher, Mindy, "The relationship between water and fuelwood availability and women's tasks in three rural communities in Oaxaca, Mexico" (1994). Master's Theses. 750.

DOI: https://doi.org/10.31979/etd.jequ-5nyk

https://scholarworks.sjsu.edu/etd_theses/750

This Thesis is brought to you for free and open access by the Master's Theses and Graduate Research at SJSU ScholarWorks. It has been accepted for inclusion in Master's Theses by an authorized administrator of SJSU ScholarWorks. For more information, please contact scholarworks@sjsu.edu. 


\section{INFORMATION TO USERS}

This manuscript has been reproduced from the microfilm master. UMI films the text directly from the original or copy submitted. Thus, some thesis and dissertation copies are in typewriter face, while others may be from any type of computer printer.

The quality of this reproduction is dependent upon the quality of the copy submitted. Broken or indistinct print, colored or poor quality illustrations and photographs, print bleedthrough, substandard margins, and improper alignment can adversely affect reproduction.

In the unlikely event that the author did not send UMI a complete manuscript and there are missing pages, these will be noted. Also, if unauthorized copyright material had to be removed, a note will indicate the deletion.

Oversize materials (e.g., maps, drawings, charts) are reproduced by sectioning the original, beginning at the upper left-hand corner and continuing from left to right in equal sections with small overlaps. Each original is also photographed in one exposure and is included in reduced form at the back of the book.

Photographs included in the original manuscript have been reproduced xerographically in this copy. Higher quality $6^{\prime \prime} \times 9^{\prime \prime}$ black and white photographic prints are available for any photographs or illustrations appearing in this copy for an additional charge. Contact UMI directly to order.

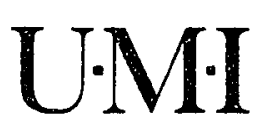

University Microfilms international

A Bell \& Howell Information Company 
Order Number 1358174

The relationship between water and fuelwood availability and women's tasks in three rural communities in Oaxaca, Mexico

Fisher, Mindy Gayle, M.S.

San Jose State University, 1994

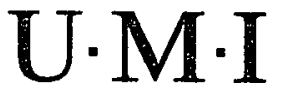

300 N. Zeeb Rd.

Ann Arbor, MI 48106 


\title{
THE RELATIONSHIP BETWEEN WATER AND FUELWOOD AVAILABILITY AND WOMEN'S TASKS IN THREE RURAL COMMUNITIES \\ IN OAXACA, MEXICO
}

\author{
A Master of Science Thesis \\ Presented to \\ The Faculty of the Department of Geography and Environmental Studies \\ San Jose State University \\ In Partial Fulfillment \\ of the Requirements for the Degree \\ Master of Science
}

By

Mindy Fisher

San Jose, California

May, 1994 
(c) 1994

Mindy Fisher

ALL RIGHTS RESERVED 
APPROVED FOR THE DEPARTMENT OF ENVIRONMENTAL STUDIES

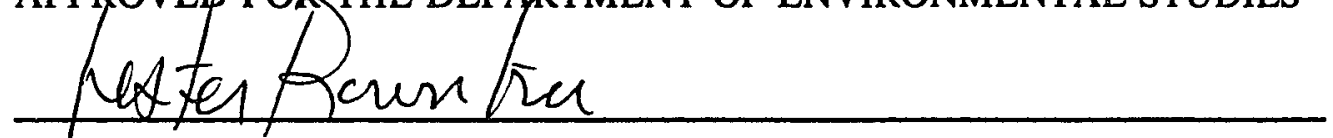

Dr. Lester Rowntree, Professor of Environmental Studies (Committee Chair)

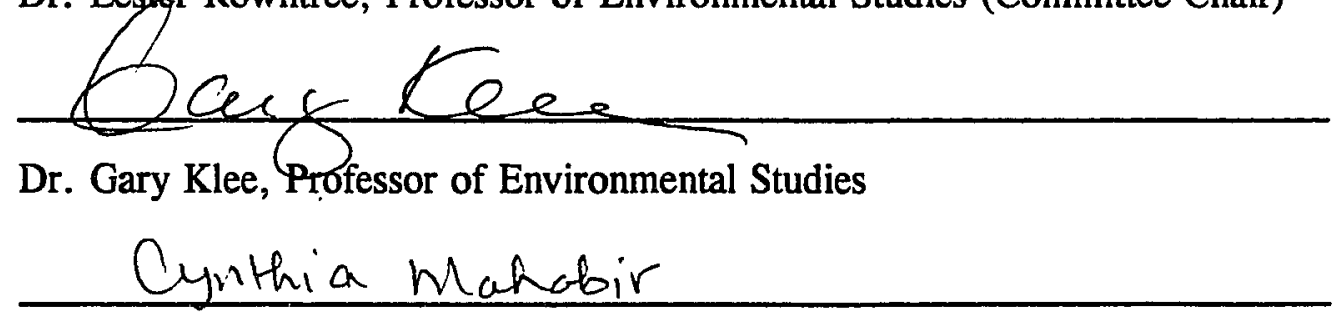

Dr. Cynthia Mahabir, Professor of Afro-American Studies

APPROVED FOR THE UNIVERSITY

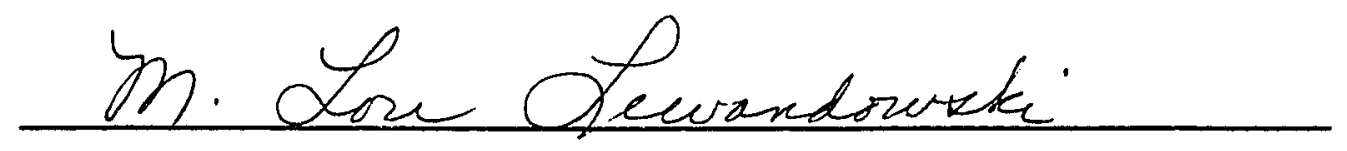




\begin{abstract}
THE RELATIONSHIP BETWEEN WATER AND FUELWOOD AVAILABILITY AND WOMEN'S TASKS IN THREE RURAL COMMUNITIES

IN OAXACA, MEXICO

by Mindy Fisher
\end{abstract}

This thesis provides three case studies that document how women are becoming victims of environmental impoverishment and how their subsequent use of scarce resources further degenerates the environment. In addressing these issues three questions were asked: How are women's lives affected by resource scarcity, how do women respond to the ensuing shortage, and what are the implications of the answers? A feminist perspective that focuses on a holistic understanding was used in formulating the research questions, directing the scope of the study, and analyzing the data.

Research on this subject reveals that women are operating under a system of crisis management. Not only is their daily work becoming more difficult, but their level of survival is also becoming more difficult to maintain. Because women are charged with finding fundamental resources, they are increasingly unable to fulfill their duties. This in turn affects the entire family. 


\section{TABLE OF CONTENTS}

ABSTRACT $\ldots \ldots \ldots \ldots \ldots \ldots \ldots \ldots \ldots \ldots \ldots \ldots \ldots \ldots \ldots \ldots$ iii

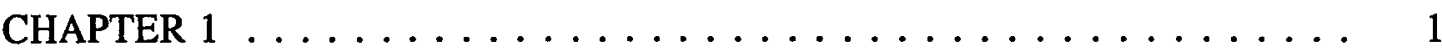

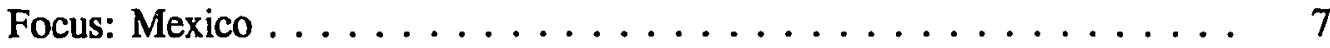

Oaxaca ...................... 9

Los Valles Centrales ....................... 13

Key Terms and Concepts $\ldots \ldots \ldots \ldots \ldots \ldots \ldots \ldots$

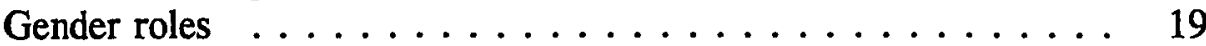

Resources ..................... 20

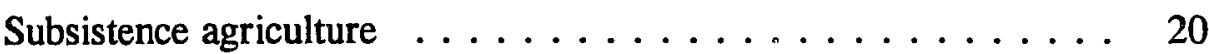

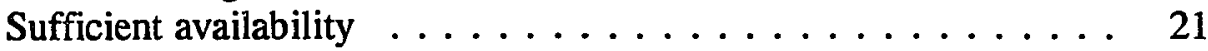

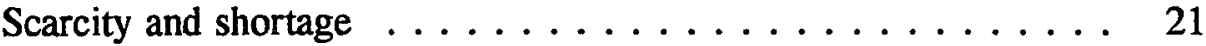

Development ..................... 21

Notes on a Feminist Perspective $\ldots \ldots \ldots \ldots \ldots \ldots \ldots \ldots . \ldots \ldots$

Overview ....................... 24

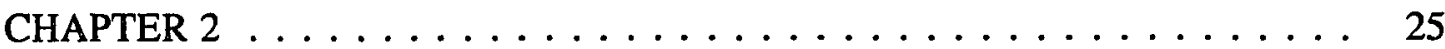

Rural Women and Work ................. 25

Economic Crisis of the $1980 \mathrm{~s} \ldots \ldots \ldots \ldots \ldots \ldots \ldots \ldots$

Ecological Impoverishment in Mexico . . . . . . . . . . . 32

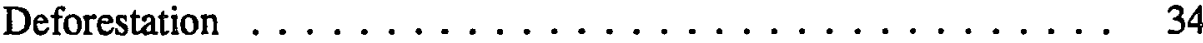

Water resources $\ldots \ldots \ldots \ldots \ldots \ldots \ldots \ldots \ldots \ldots \ldots$

Pesticides. . .................. 36

Women and Development in Mexico .............. 37

A Representative Model of Women and Development . . . . . . . . 39

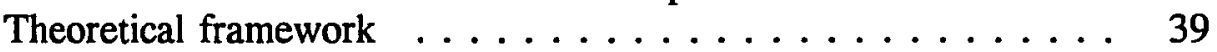

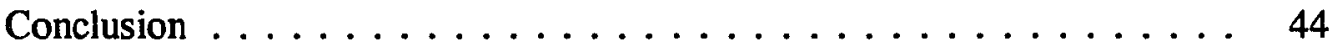

CHAPTER $3 \ldots \ldots \ldots \ldots \ldots \ldots \ldots \ldots \ldots \ldots \ldots \ldots \ldots \ldots \ldots \ldots \ldots$

Principles of the Feminist Perspective $\ldots \ldots \ldots \ldots \ldots \ldots \ldots \ldots 48$

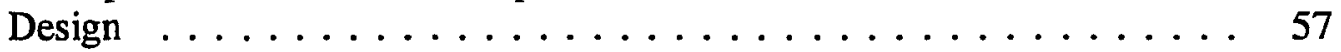

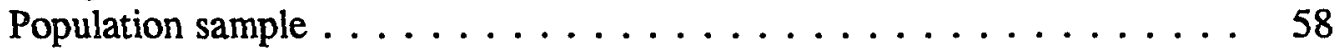

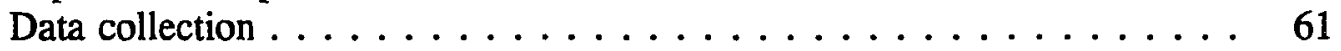

Conclusion .................... 62 


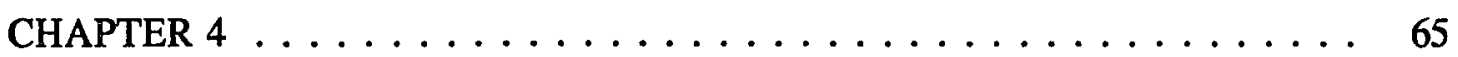

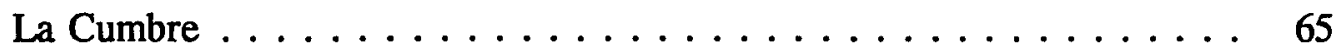

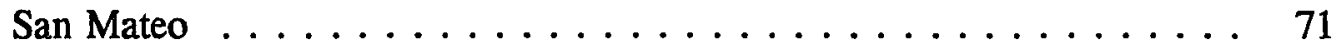

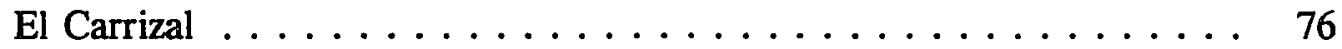

Analysis $\ldots \ldots \ldots \ldots \ldots \ldots \ldots \ldots \ldots \ldots \ldots \ldots \ldots \ldots$

Answers to questions $\ldots \ldots \ldots \ldots \ldots \ldots \ldots \ldots$

Deforestation .................... 84

Water scarcity $\ldots \ldots \ldots \ldots \ldots \ldots \ldots \ldots \ldots \ldots$

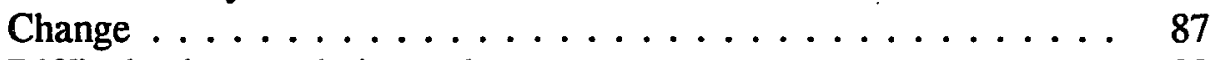

Difficulty in completing tasks $\ldots \ldots \ldots \ldots \ldots \ldots . \ldots 8$

Development .................... 88

Looking at the Larger Issues $\ldots \ldots \ldots \ldots \ldots \ldots \ldots$. . . . . . 89

Conclusion ..................... 91

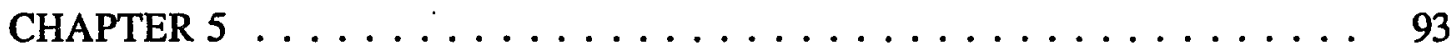

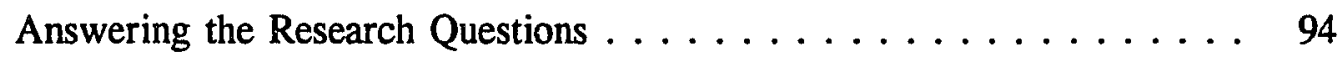

Global Implications . . . . . . . . . . . . . . . . 97

Suggestions for Future Research $\ldots \ldots \ldots \ldots \ldots \ldots \ldots \ldots$

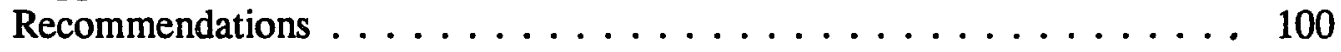

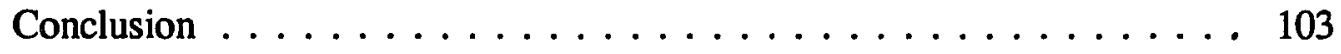

REFERENCES . . . . . . . . . . . . . . . . . . 106 


\section{LIST OF ILLUSTRATIONS}

$\begin{array}{lll}\text { Figure Page } & \text { Par }\end{array}$

1. Influencing factors in a stable environment $\ldots \ldots \ldots \ldots$

2. Location of Oaxaca . . . . . . . . . . . . . . . . 10

3. The Central Valley of Oaxaca . . . . . . . . . . . . . . . . 14

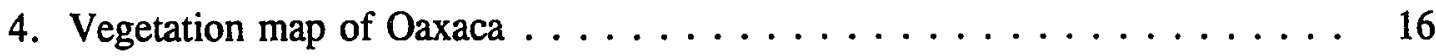

5. Map showing mean annual precipitation rates in Oaxaca $\ldots \ldots \ldots \ldots$

6. Map depicting soil erosion levels in Oaxaca $\ldots \ldots \ldots \ldots \ldots \ldots$

7. Data questionnaire ...................... 63

8. Communal farming area in La Cumbre marked by erosion $\ldots \ldots \ldots \ldots$

9. Erosion in La Cumbre farming area . . . . . . . . . . . . . . . 69

10. Deforestation in the hills surrounding San Matso . . . . . . . . . 73

11. Pipe system providing water to San Mateo . . . . . . . . . . . . 74

12. Deforested hills of El Carrizal $\ldots \ldots \ldots \ldots \ldots \ldots$

13. Deforestation in El Carrizal . . . . . . . . . . . . . . 79 


\section{LIST OF TABLES}

Table

Page

1. The gendered division of labor $\ldots \ldots \ldots \ldots \ldots \ldots$

2. Contemporary research models $\ldots \ldots \ldots \ldots \ldots \ldots \ldots$

3. Data chart on the three villages studied $\ldots \ldots \ldots \ldots \ldots$. . . . . 82

4. Answers to questions $\ldots \ldots \ldots \ldots \ldots \ldots \ldots$

5. Suggestions for future research $\ldots \ldots \ldots \ldots \ldots$. . . . . . . . 100 


\section{CHAPTER 1}

\section{OAXACAN WOMEN AND ENVIRONMENTAL DETERIORATION: AN INTRODUCTION TO THE PROBLEM}

The increasing deterioration of the environment is affecting people everywhere. For poor rural women, however, it has particular significance. Recent studies (Stephen 1992; Dankelman and Davidson 1989; Sontheimer 1991; Rodda 1991) highlight rural women's dependence on natural resources and explain that women are responsible for providing fuelwood, water, and food for their families. In Third World countries plagued by environmental degradation, an impoverished ecological base makes it more difficult for women to supply their families with basic necessities; resources once extracted from the natural environment are now harder to find (Stephen 1992; Sontheimer 1991). Faced with widespread resource scarcity, economic poverty, and the need to maintain traditional reproductive roles, rural women are forced to choose among equally important tasks (Rodda 1991).

Throughout most of the world the increasing deterioration of natural resources is caused in part by the direct result of irresponsible development projects aimed at producing for the global economy (Rodda 1991). This type of development, called uneven development, has contributed to wide-scale deforestation, conversion of woodland for agricultural development, the indiscriminate use of water sources for 
irrigation, and the privatization of communal land (O'Connor 1989; Sontheimer 1991; Dankelman and Davidson 1989; Goldrich and Carruthers 1992; Maguire and Brown 1986; and Rodda 1991). These changes in land use have drastically affected the rural poor, leaving them with a degraded ecological base and less access to land (O'Connor 1989). Because many rural families live at a subsistence level producing only enough to satisfy familial needs, environmental degradation threatens their very existence. Rural people are caught in a trap of environmental scarcity, which they then contribute to in their attempts to satisfy basic human needs. In order to extract enough food, water, and wood from the land to satisfy their families, rural people degrade the land even further by using the last remaining materials. Thus begins the cycle that leads from environmental degradation to familial resource hunger, which in turn causes more environmental destruction (Fig. 1).

The impact of scarcity has been particularly difficult for women, whose primary responsibilities include gathering wood and water (see Table 1; Sontheimer 1991; Dankelman and Davidson 1989; Rodda 1991; and Wignaraja 1990). Men also experience stress from environmental problems, but their habits and ethnographies are already well documented; most previous anthropological and geographic data has concentrated on the male perspective.

This thesis examines the effects of water and fuelwood scarcity on women's lives in three rural communities in Oaxaca, Mexico (Fig. 2). In La Cumbre, San Mateo, and El Carrizal, communities are fighting to maintain their traditional 


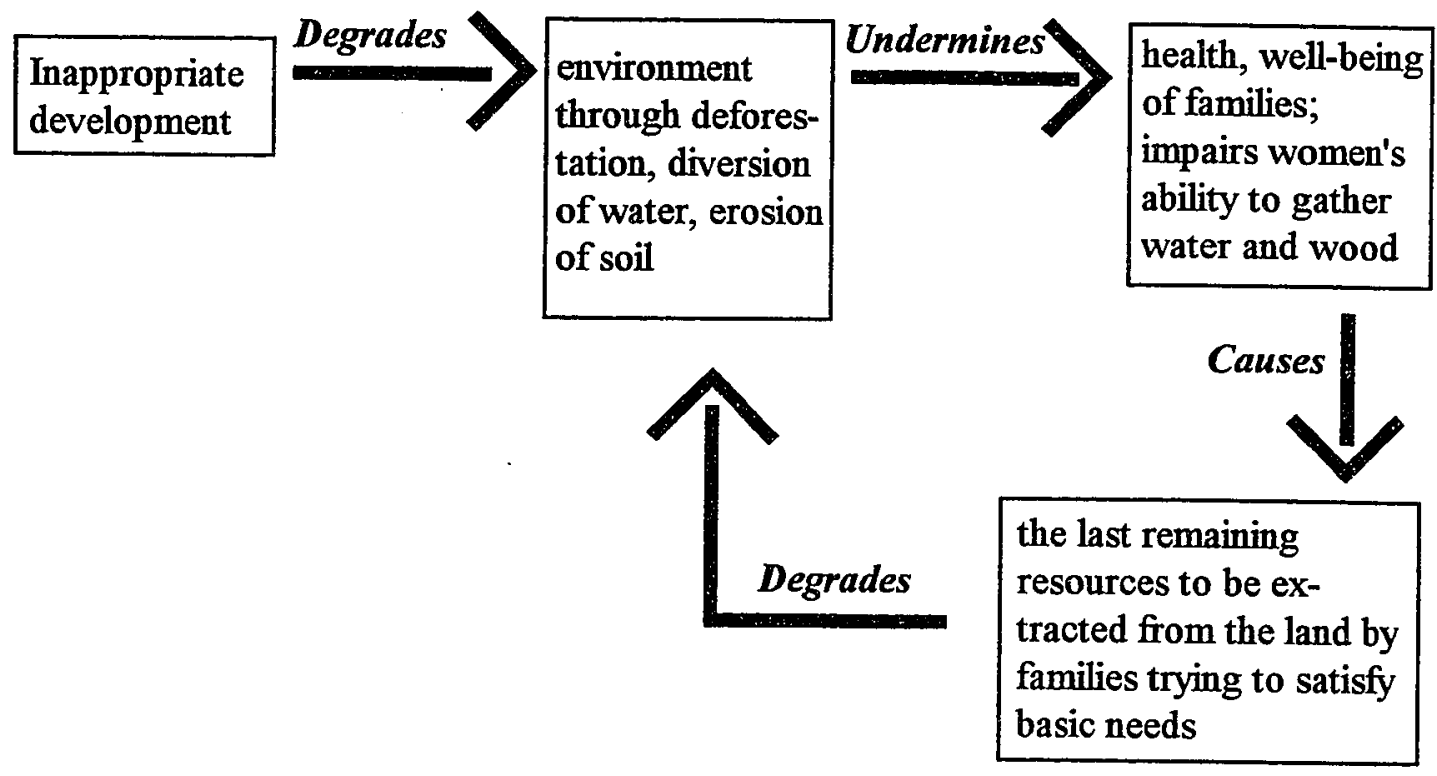

THE SUSTAINABLE LOOP

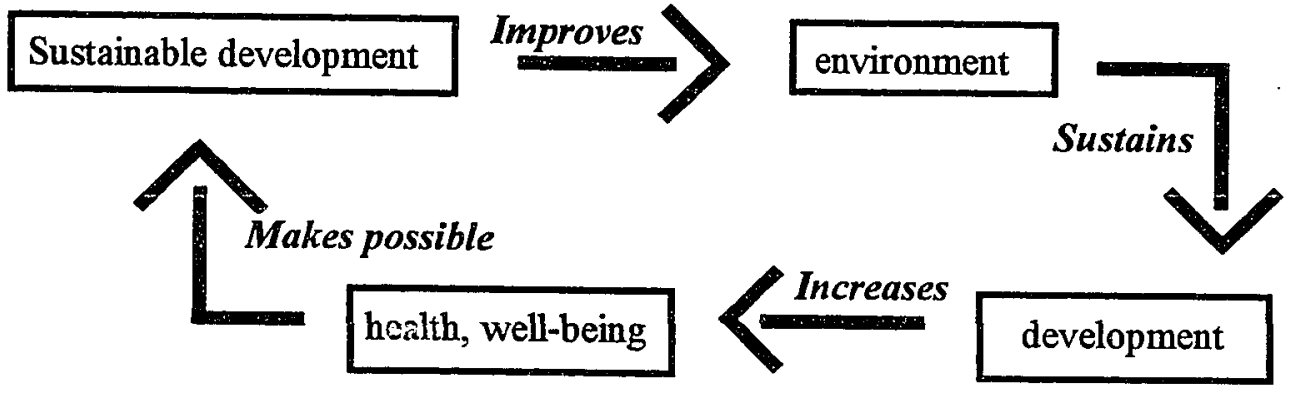

Figure 1. Influencing factors in a stable environment. 
TABLE 1

THE GENDERED DIVISION OF LABOR:

A SAMPLING OF TRADITIONAL TASKS

\begin{tabular}{||l|l||}
\hline Female & Male \\
\hline Seeding & Seeding \\
\hline Weeding & Plowing \\
\hline Harvesting & Cultivating crops \\
\hline Processing grains & Migratory wage labor \\
\hline Crop cultivation & \\
\hline Animal maintenance & \\
\hline Selling foods at market & \\
\hline Cooking & \\
\hline Washing & \\
\hline Gathering fuelwood & \\
\hline Hauling water & \\
\hline Child care & \\
\hline Tending to sick and elderly & \\
\hline Sewing & \\
\hline Cleaning & \\
\hline Craft making & \\
\hline
\end{tabular}

Source: Adapted from Lourdes Beneria, Women and Development: The Sexual Division of Labor in Rural Societies. (New York: Praeger Publishers, 1982). 
lifestyles. This study also examines how environmental degradation, most often initiated by uneven development, disproportionately affects women. Given the literature on Africa, Asia, and Latin America (Rodda 1991; Dankelman and Davidson 1989; Stephen 1992; Sontheimer 1991; Wignaraja 1990; Arizpe and Botey 1987), we can expect that women will work longer hours when resources are scarce. Although there are studies on rural Mexican women (Stephen 1992; Arizpe and Botey 1987), we do not find many that look at how environmental degradation is specifically impacting rural women's daily lives.

In the communities studied, people engage in farming solely to provide food for their families. Household tasks are divided along discrete gender lines, leaving the women responsible for maintaining the family. Because these tasks are essential to familial survival (by providing water for drinking and washing, and wood for fuel), this thesis will examine the links between degradation of these resources and their effects on women's ability to provide for their families. While it is important to understand that the findings will be unique to the specific villages studied, the data obtained can be used to start a foundation of information for similar villages in Mexico.

An important aspect of this study is the guidance of a feminist perspective. This perspective stresses a holistic orientation and discourages discrete research questions (Cook and Fonow 1986). According to Susan Geiger (1992), there are two feminist objectives in research. The first emphasizes an understanding of the issue 
rather than controlling the information generated. The second conceptualizes the interpretive task as one of opening rather than one of closure (Geiger 1992, 306).

This study is interested not in the mathematical rates of environmental depletion, but in the subjective experience of Oaxacan women. How the women perceive their situation is the crucial issue because behaviors are a function of attitude and belief, rather than numerical realities. The feminist perspective supports case studies as a means of documenting the subjective experiences of women's lives for future secondary analysis and future action on behalf of women (Reinharz 1992, 171).

Three open-ended questions were used to examine this topic: How are women affected by water and fuelwood shortages? How do women respond to the shortages? And what are the implications of the answers? The feminist perspective called for inductive analysis and supported the formulation of new questions during the research process.

Environmental studies often demands scientific methods and discrete hypotheses, yet this study warrants subjectivity. Although this thesis draws upon many disciplines, including anthropology, sociology, geography, and ecology, it falls into the realm of environmental studies because it examines the interplay between humans and the environment and explores the dynamics of environmental degradation. Like this thesis, environmental studies involves the holistic study of complex environmental relationships.

In addition to the questions guiding the study, this thesis supports the idea that 
rural women hold the key to knowledge of environmental conditions because they work closely with the natural environment. Because women are responsible for maintaining the reproductive tasks of the family, they possess knowledge regarding family needs and often have insight into the depletion of nearby natural resources necessary for family survival. The underlying goal in rural women's tasks is one of ensuring survival. The most prudent way to ensure survival is to maintain an abundance of natural resources. It is in the best interest of women therefore to preserve the environment. Rural women are among the first to understand when there is a problem of environmental destruction because of their knowledge of the natural surrounding conditions, which makes them living resource libraries. They understand their basic survival needs and should be included in designing plans to rejuvenate depleted areas.

\section{Focus: Mexico}

We often think of the Third World as a distant place in another hemisphere and forget that our neighbor Mexico is a largely poor rural nation faced with widespread poverty and environmental degradation. The recent push for increased trade with Mexico has led us to believe that development has raised the standard of living for the Mexican people. Unfortunately, for many rural peasants development has signified a governmental shift away from social programs to more economically profitable policies supporting businesses. This uneven development has caused spatially distributed pockets of poverty in rural areas that are not supported by either 
governmental programs or business profits (Wignaraja 1990). Furthermore, prime agricultural land has been taken up by agribusinesses, leaving rural people with the most marginal land (Wignaraja 1990). This land, often steeply sloped with poor soil, is difficult to farm and prone to erosion. Not only has the disappearance of social welfare programs contributed to economic poverty for rural peasants, but the move to marginal land has caused widespread resource poverty as well.

Ecological degradation and rural poverty are not static issues, but rather problems increasing in intensity. For example, experts claim that Mexico is losing over $2000 \mathrm{~km}^{2}$ of farmland per year to desertification (Myers 1989, 36), while forest losses are estimated at an annual rate of $400,000 \mathrm{~km}^{2}$ (Nuccio, Ornelas, and Restrepo 1990, 26). We must clearly examine our role in these economic and ecological issues, as the problems may be exacerbated by the adoption of policies such as NAFTA and the globalization of trade (Goldrich and Carruthers 1992).

The history of Mexico's uneven development can be traced back within the last 50 years. During this time Mexico has undergone an agricultural and economic transformation, resulting in increased capital gains for the government and the country's elite, and heightened poverty for the rural peasants (Stephen 1992). Not only have the economic aspects of capitalization upset traditional peasant life, but the environmental.degradation caused by modern agricultural techniques and increased population pressure have contributed as well. Impoverishment in the form of landlessness, fuelwood shortages, lack of access to safe water, underemployment, 
deteriorating health conditions, and cutbacks in social services has forced rural people to adapt to changing circumstances. Although many peasants attempt to live at a subsistence level, it is also important to understand that the lack of arable land, drought, malnourishment, and illness force them to seek out social and economic aid. Many people migrate to larger, urban areas in order to earn supplemental wages, while others attempt to sell certain crops. In most instances, they remain poor, however, as both government and the economic climate cannot augment their needs. Mexico's recent push for development has incorporated rural agricultural programs, drainage systems, educational programs, and community organizing initiatives (Dalton 1991; Grindle 1977). The links between women's work, resource scarcity and environmental degradation are not fully understood, and therefore the effects of these development projects are not clear. Examining these links will help us understand the interplay between people and the environment. Furthermore, it is crucial that the experiences of women be considered so that a holistic understanding may be achieved.

\section{Oaxaca}

Sandwiched between Chiapas to the south and the modern farming areas near Mexico City to the north, Oaxaca's rural dwellers maintain an autonomous existence much different from that of rural peasants elsewhere in Mexico (Alvarez 1983) (Fig. 2). The lack of exploitative urban centers and over-commercialization allow Oaxaca's rural peasants to participate in subsistence agriculture. The absence of aggressive 


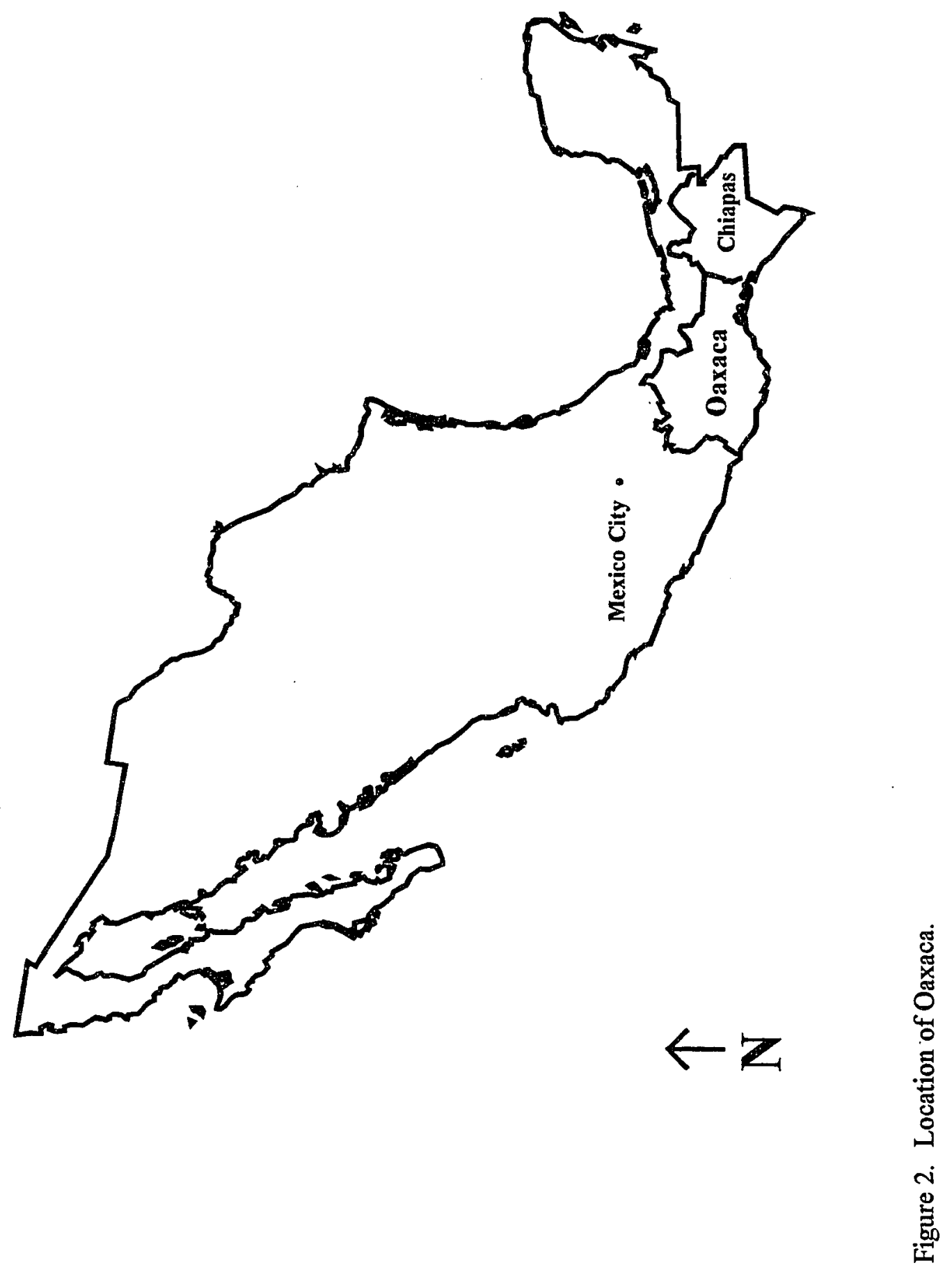


economic expansion however, has contributed to impoverishment." In a 1983 survey of 3,281 towns, 31 percent had some sort of potable water network, while 69 percent lacked piped water; only 2 percent of the towns had a drainage system, 1 percent had paved roads, and a mere 2 percent of the towns benefitted from sanitation services, with only four of those towns maintaining garbage collection trucks (Alvarez 1983, 128). According to Clarke, the impoverishment of Oaxaquenos is due to the lack of natural resources and to the incomplete penetration of the state by agrarian capital (Clarke 1986, 5).

The state of Oaxaca expands over $95,000 \mathrm{~km}^{2}$ and is located on the Pacific Coast of southern Mexico. Most of the state is mountainous, and elevations in excess of 2000 meters are recorded in the Mixteca Alta, the Sierra Zapoteca, and the Sierra Madre del Sur, on the northern and southern limits of the state (Clarke 1986, 6). Many highland communities are highly inaccessible due to the difficulty of the terrain. Often times it is possible to visit minor towns and villages away from the main valley systems only by jeep, truck or even mule, or not at all during the rainy season from April to October. Accelerated soil erosion, land-hunger, malnourishment, and disease plague many Oaxacan communities, especially those at high altitudes (Clarke 1986, 6)

\footnotetext{
*n According to the 1968 census, Oaxaca had the second highest general mortality rate and the highest rate of morbidity in Mexico. Oaxaca also ranked among the lowest states in wheat production, food consumption, and housing adequacy, and had the second highest rate of illiteracy," from Cook and Diskin 1976, 24. Although this data is not recent, Clarke (1986) maintains that mortality and social welfare trends in Oaxaca have been steadily declining for the last 30 years.
} 
This countryside provides the setting for over 2 million inhabitants." Almost half the population speaks one of more than a dozen Indigenous languages, though the majority are also proficient in Spanish (Clarke 1986, 6). The greatest densities of population are located beneath the mist forest, the pine and oak woodlands and the mesquite-covered lower slopes in the warmer regions on the periphery of the mountain mass or in entrenched river valleys and mountain basins in the more temperate areas (Clarke 1986, 9).

As in most of Mexico, Oaxaquenos produce staples of corn, beans, and squash for subsistence. In many areas, the campesinos plant on heavily sloped areas, which increases runoff and ultimately, soil erosion. Furthermore, the practice of burning vegetation in order to create a plot for subsistence also furthers erosion by eliminating cover vegetation and leaving the area vulnerable to wind and rain (Alvarez 1983, 77). Often times plots are burned to kill harmful insects and initiate pasture growth (Alvarez 1983, 77).

The economic situation in Oaxaca is difficult and bleak for many of the poorer campesinos. Agricultural adaptation by altitude and locality allows an inter-trade of foodstuffs, and the production of textiles provides further exchange. This peasant system of production, exchange, and consumption has been put under increasing population pressure since the Mexican Revolution. Between 1920 and 1970, the population of the state increased by 122.5 percent, and during the 1960 s it was

\footnotetext{
* Alvarez estimates the 1983 population at 2,689,400 (Alvarez 1983, 115).
} 
growing annually by 2.6 percent (Clarke 1986,9$). *$ Migration to the city of Oaxaca, northern Mexico, and the United States, may be the result of the increased pressure on resources.

\section{Los Valles Centrales}

The three villages examined in this study, La Cumbre, San Mateo, and El Carrizal, are located in the Valley of Oaxaca (Fig.3). The Valley contains the districts of El Centro, Ejutla, Etla, Ocotlan, Tlacolula, Zaachila, and Zimatlan. It covers an area of $8,762 \mathrm{~km}^{2}$ and supports 436,302 inhabitants (Acevedo and Restrepo 1991, 15). La Cumbre, San Mateo, and El Carrizal are all located in the municipality of Zimatlan. The seven districts contain 121 municipals and 444 localities. The majority of these localities have less than 1000 inhabitants, which makes social and economic integration difficult because they are small and removed from urban centers (Acevedo and Restrepo 1991, 15). While many different types of indigenous people live in the Valley, the majority are from either the Zapotec or Mixtec group, and many are mestizos (Acevedo and Restrepo 1991).

The Valley is actually comprised of three geological links, each 20 to $30 \mathrm{~km}$ long. Each valley was formed by tertiary down faulting, and the steep-sided boundary slopes have developed across metamorphic rocks; the valley bottoms are broad and flat and filled with alluvial deposits (Clarke 1986, 11). The average

"Mexico's current national rate of population growth is 1.8 percent, from $\underline{\text { San Jose }}$ Mercury News, 11 November 1993, 14A. 


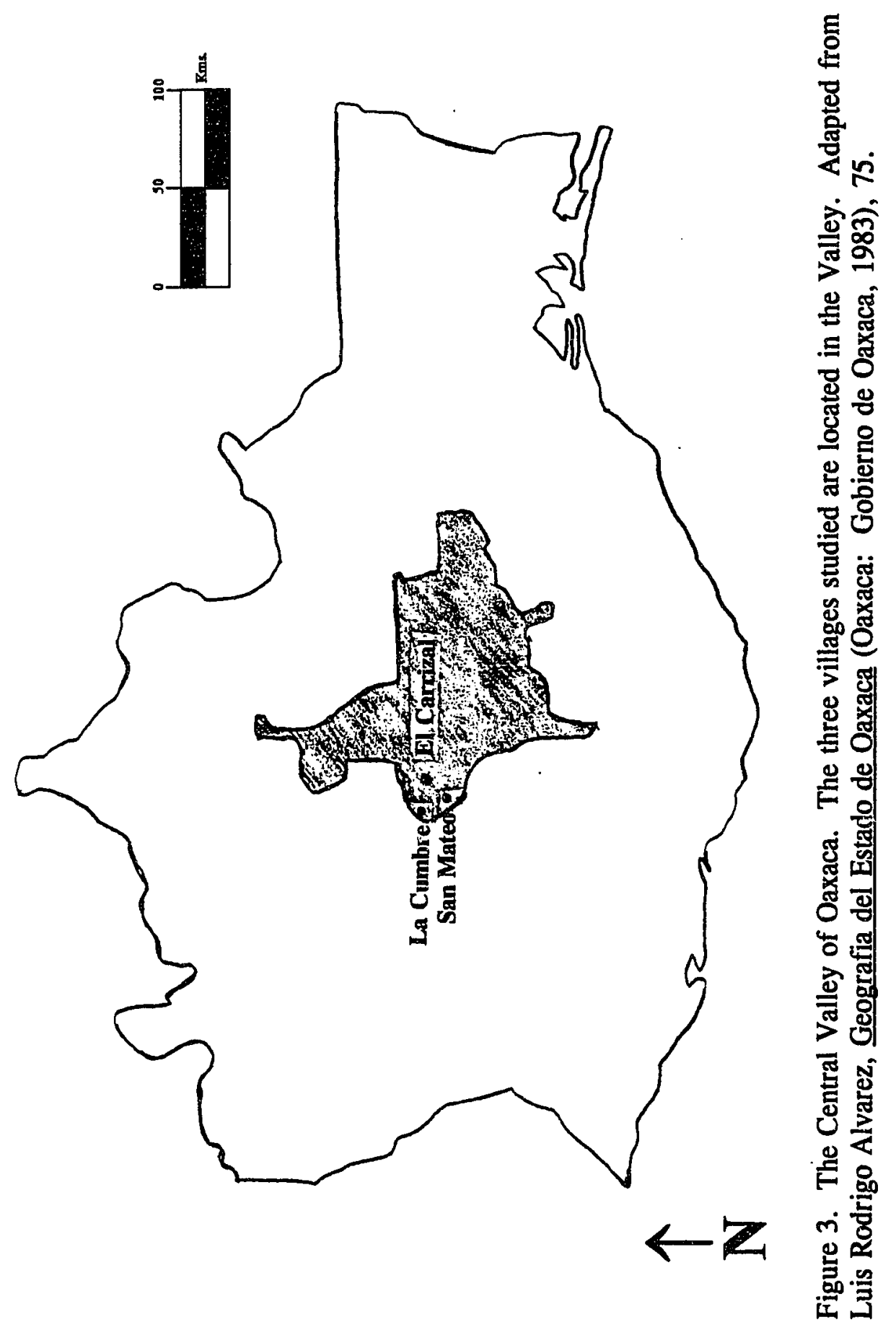


altitude is $1,500 \mathrm{~m}$ and the climate is temperate, yet the varied topography gives rise to important differences in rainfall over short distances (Clarke 1986, 11) (Fig. 4). Precipitation ranges from $600 \mathrm{~mm}$ to $750 \mathrm{~mm}$, with an average of $650 \mathrm{~mm}$ (Fig. 5). Land in the Valley may be classified as montane slope, piedmont, or alluvial (Clarke 1986, 13). Most montane slopes are inadequate for cultivation, as the slopes are steep and soils are poor and dry. However, many peasants utilize these steep slopes by engaging in slash and burn shifting cultivation. This type of farming requires great strength and endurance because it is physically difficult to work on the steep slopes. Furthermore, the poor soil condition makes it necessary for farmers to clear large portions of land to increase the likelihood of harvesting enough food for the family (Fig. 6). Irrigation is a problem in the Valley, as water is limited. At one time there were many small rivers running through the Valley. Today many of these rivers are dry. The most important water system now is the Rio Atoyac, which traverses the state and eventually drains into the Pacific Ocean (Acevedo and Restrepo $1991,17)$.

The most common economy in the Valley is agriculture. A gendered division of labor is evident, with the men participating in subsistence agricultural work and the women assisting in subsistence agricultural work and assuming the responsibility for family maintenance (Acevedo and Restrepo 1991, 34). The Valley is plagued with the same problems affecting the rest of the state, namely poverty, illiteracy, and land hunger (Acevedo and Restrepo 1991). 


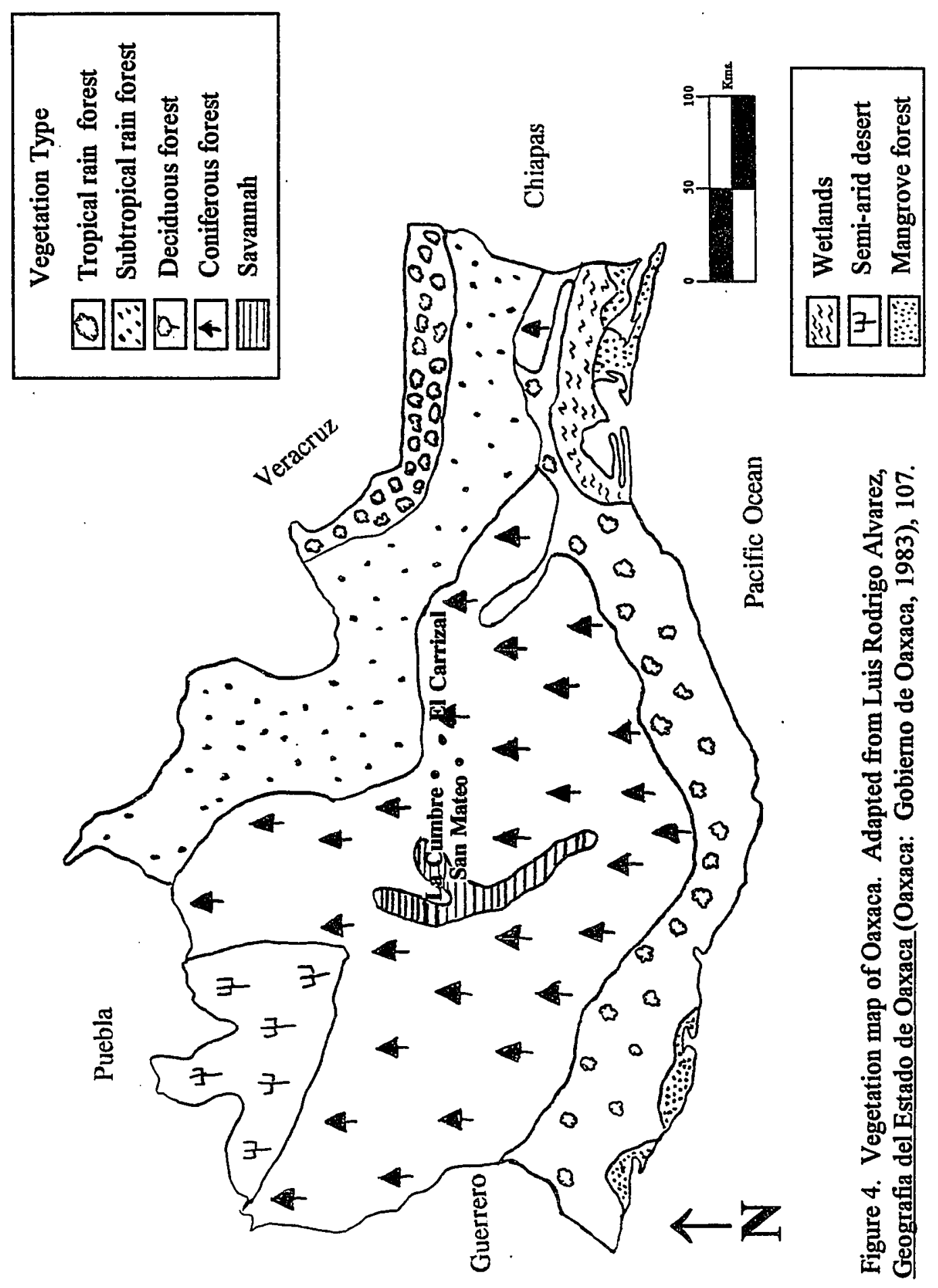




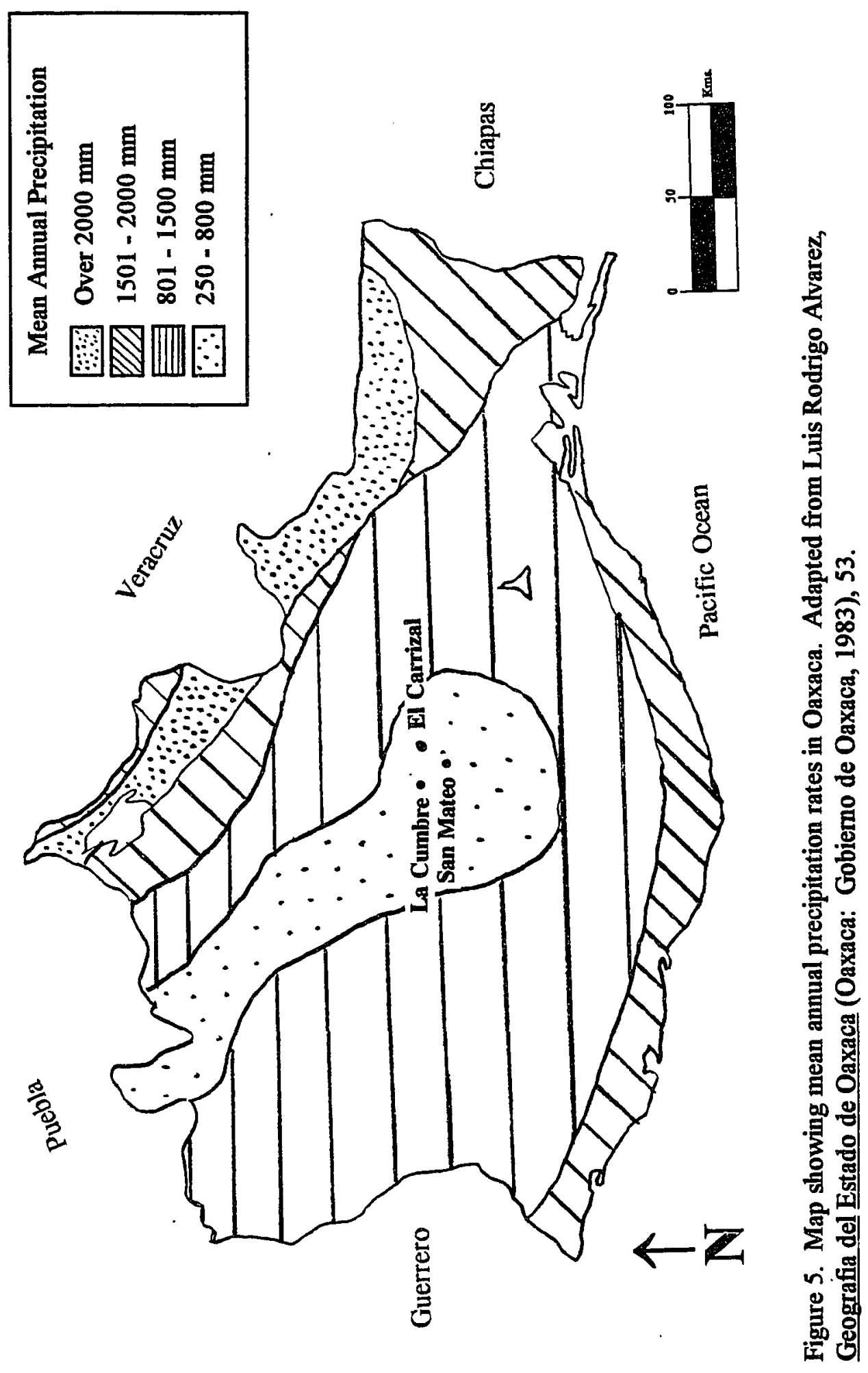




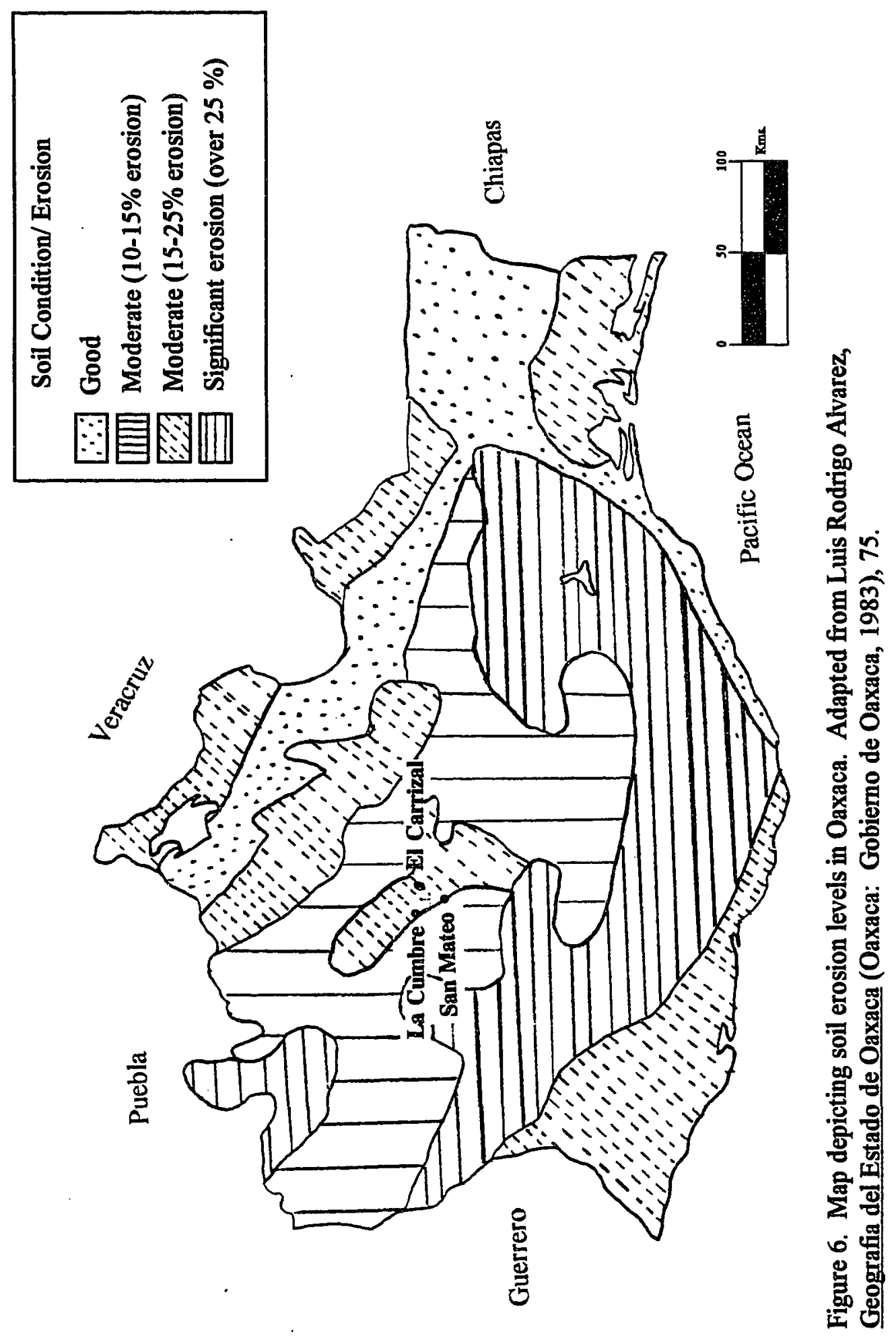




\section{Key Terms and Concepts}

Because this study draws from many different disciplines, anthropology, geography, and sociology among others, it is necessary to operationalize various definitions in order to clarify key terms. While the meanings of these terms vary slightly throughout the thesis, the underlying connotations are defined as follows:

Gender roles. A role can be defined in terms of a cluster of socially or culturally defined expectations that individuals in a given situation are expected to fulfill (Chafetz 1974, 3). In other words, the expected behavior associated with any given status is referred to as a role (Lindsey 1990,1 ). A status is the social category or position that determine how members of society will be defined and treated. Females and males, mothers and fathers, and daughters and sons are all statuses with different role requirements attached to them. Roles and statuses are key components of social structure and are necessary in helping us organize our lives in a consistent and predictable manner (Lindsey 1991, 2).

Gender involves those social, cultural, and psychological aspects linked to males and females through particular social contexts (Lindsey 1991, 2). What a given society defines as masculine or feminine is a component of gender. Therefore gender roles refer to the attitudes and behaviors the members of a society are expected to act out. Thus gender roles include the rights and obligations that are normative for the sexes in a given society.

In Latin America, women experience a lower status than men. According to 
Lindsey, unequal economic opportunities and the penetration of machismo have negatively affected rural women. Furthermore, because women's heavy domestic responsibilities impede upon their abilities to leave the home and obtain work, they do not have economic mobility. Men, however, do not share the domestic work and enjoy more economic opportunities. In this society, the gender roles assigned to women lead to inequality, and their worth is lessened by the attitude that women are not productive (Lindsey 1991, 98). A more in-depth discussion of women's roles is discussed later.

Resources. In order to limit the scope of this study and provide a more detailed analysis of women's relationship to resource management, it is necessary to narrow the definition of "resources." Resources can be defined as

the natural endowments of a location or country which can be considered resources with regard to their numbers, intelligence and skills. Natural resources are phenomena used to produce economic goods or to provide services, such as land or lakes for food production; oil, natural gas, fast flowing rivers, or waterfalls for energy; forests and minerals as raw materials; and so on (Welsh and Butorin 1990, 942).

More specifically, natural resources are forests, minerals, soils, and water. Families depend upon water for drinking, cooking, and washing, wood and forest products for fuel and food, and land for food production. Rural communities are dependent upon all of these natural resources, but for the purpose of this thesis, "resources" will refer to the water and fuelwood available for personal consumption.

Subsistence agriculture. Subsistence agriculture is best defined as "family- 
oriented farming that ordinarily produces only enough food for the family's needs, with no surplus for sale" (Welsh and Butorin 1990, 942). As previously stated, however, subsistence living is an almost impossible task in rural Mexico. Often times family members engage in wage labor in order to supplement subsistence agriculture, or perhaps even sell certain crops. For the purposes of this study, a broad definition of subsistence will include families attempting to farm only enough food for their personal consumption.

Sufficient availability. The term "sufficient availability" describes the ability to meet the family's food needs through subsistence agriculture. Sufficient availability is only used in the context of this thesis to help define the belief that enough resources are available to satisfy personal wants and needs. There is sufficient availability of resources if the family believes their needs of obtaining fuelwood and water are met. The term "adequate" is also used in this context.

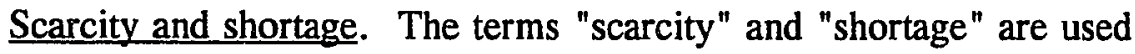
interchangeably. They refer to the belief that there are fewer resources than are needed. For example, a shortage of fuelwood signifies that the people need more woed to meet their demands. Water scarcity implies that there is not enough water to satisfy personal and familial needs.

Development. Development is the process of economic or social betterment resulting from increased production, the adoption of principles of national or individual conduct more conducive to economic growth, and general structural changes in a society (Welsh and 
Butorin 1990, 310).

Development may lead to a higher standard of living in terms of income, education,

health, housing, and other forms of consumption (Welsh and Butorin 1990, 310).

Welsh and Butorin define development policy as the

government's ideas concerning the type of development to be achieved and the means to achieve it, enshrined in legislation...The philosophy may stress export orientation or import substitution, policies relying on foreign investment or self-reliance, agriculture or industry, wealth redistribution...(320).

\section{Notes on a Feminist Perspective}

The purpose of this thesis is to show how Oaxacan women's lives are affected by resource shortages and how the women respond. In accordance with a feminist perspective there is no overriding hypothesis; instead several questions are explored and in the process various observations and additional questions surfaced. The questions examined in this thesis are

- How are women affected by water and fuelwood shortages?

- How are women responding to the shortages?

- What are the implications of these answers?

The growing body of literature concerning rural Third World women and the environment emphasizes that as natural resources become scarce, women's tasks associated with collecting those resources and maintaining the family become more difficult. This relationship is explored in La Cumbre, San Mateo, and El Carrizal where women are charged with finding fuelwood and water for their families.

Several linear questions were formulated in order to answer the larger research 
questions. These specific questions include

- Is fuelwood/water increasing or decreasing in the villages?

- Are women spending more time collecting wood/water?

- Do the women perceive their burdens as being heavier?

- Have any type of development projects occurred in response to these issues?

- If so, are they perceived as successful responses?

- Is there a difference in these patterns among villages?

Chapter 4 provides an in-depth analysis of these questions and answers.

The process of observing and interviewing the women has shed valuable information concerning these issues. Specifically, two other questions have become evident during the course of this study and are addressed in the conclusion: What short term solutions can be implemented to relieve the stress on the natural environment and alleviate the burden on rural women, and what long-term solutions can help rural peasants cope with the ramifications of uneven development?

In examining women's relationship to resource scarcity this study draws upon existing sociological, geographic, and ethnographic literature to validate various assumptions relating to the research questions. A literature review provides the basis for the conceptual framework prevalent in this thesis and answers

- How are women tied to natural resource availability?

- How has the Mexican government's economic policies hurt rural women?

- What is the state of Mexico's environment?

- Are alternative development plans that incorporate women being pursued in Mexico?

- Is there a model that provides theoretical support in rethinking how we relate women and the environment?

The following chapter answers these questions and elucidates the complexities of the 
women-environment relationship.

\section{Overview}

This thesis contains five chapters. This first chapter introduces the research questions and relevant issues. The second chapter draws together relevant literature and validates assumptions concerning women's roles in rural Mexico, the effects of uneven development on rural households and women, environmental degradation in Mexico, and current theoretical models linking women and the environment.

The third chapter explains the research design. The implications of a feminist perspective on research methods are examined, as well as their specific influence on this study. The fourth chapter is the analysis which examines the field research and evaluates the data. The final chapter concludes the thesis with a discussion, recommendations, and suggestions for future research. 


\section{CHAPTER 2}

\section{THE LITERATURE REVIEW AS CONCEPTUAL FRAMEWORK}

This thesis is concerned with how wood and water scarcity affect women's

lives, in what ways women are responding to this scarcity, and what conclusions can be drawn from these issues. This study is based upon the following assumptions:

- Rural women are directly tied to natural resource availability because the gendered division of labor dictates that women act as natural resource gatherers for the family.

- The Mexican government's economic policies have promoted uneven development that directly hurts rural peasants, especially women.

- Ecological impoverishment in Mexico is widespread and advanced.

- Appropriate development for women is being pursued in Mexico and is therefore a realistic possibility.

- Feminist environmentalism, a model that relates women's experiences and environmental realities, offers a representative philosophy that suggests rethinking the way we study women and the environment.

The following literature review explains these assumptions and elucidates the conceptual framework guiding this thesis.

Rural Women and Work

A large part of this study focuses on the importance of women in relation to the environment and development. In developing countries, where traditional gender roles designate women as collectors, users and producers of natural resources, 
women's relationship to natural resource availability is vital to their daily life.

Specifically, two s\% (( ((one by Arizpe and Botey and the other by Stephen, examine women's relationship to resource use. Both studies delineate women's position in rural families and shed light on recent adjustments to economic change in Mexico.

According to Arizpe and Botey in their 1987 study entitled Mexican Agricultural Development Policy and Its Impact on Rural Women, gendered responsibilities tend to be rigid, based on cultural norms, and the role of women is oriented primarily toward the production of use values for family consumption (Arizpe and Botey 1987, 76). Arizpe and Botey report that in rural subsistence societies, Mexican women also participate in agricultural production, with the degree of participation dependent on the internal composition of the family labor unit. Some tasks, such as carrying food to the men working in the fields, planting and harvesting, raising vegetables, and caring for the smaller livestock are considered exclusively women's work (Arizpe and Botey 1987, 76). If male family members are unavailable for work, women's responsibilities expand to include traditional male roles, such as plowing, weeding, harvesting both subsistence and cash crops, irrigation, and transportation.

Arizpe and Botey believe Mexico's goals of industrialization led to a pro-urban model that inherently undermined the peasant sector (Arizpe and Botey 1987, 73). As government investment in agriculture declined, so did the incomes of rural farmers. They report that the first rural crisis was evident in agriculture production where the 
annual growth rate fell from 4.2 percent in $1955-1965$ to 1.2 percent between 1967 1970, and 0.2 percent during the 1970-1974 period (Arizpe and Botey 1987, 73). The cause of this crisis can be found in the restructuring of rural production, in which Mexico was no longer sufficient in food production, but rather emphasized international participation in the agricultural sector (Arizpe and Botey 1987, 74).

Arizpe and Botey point out that this agrarian transformation has changed the way low-income rural women participate in production and social reproduction (Arizpe and Botey 1987:74). They cite increased female migration to urban centers and a change in rural family land practices as consequences of the agrarian crisis. They explain the expansion of the rural female proletariat as follows:

Women from rural communities migrate to the urban areas in search of work in the informal and service sectors. Rural women have thus played a central role in shaping the three basic characteristics of recent Mexican development: the rural exodus, the expansion of the urban service sector, and the growth of the informal sector of the economy (Arizpe and Botey 1987, 74).

The change in family land practices, according to Arizpe and Botey, is one that encourages rural farmers to help repay the foreign debt by increasing the production of export crops, which means that families must buy their food on the open market (Arizpe and Botey 1987, 75). For rural women

this expectation has meant heavier work loads while family health and nutrition deteriorate. Women have also had to compensate for this unequal exchange, either by intensifying their unpaid labor on the family plot, entering the wage labor force, or reducing their own personal food consumption (Arizpe and Botey 1987, 75).

Arizpe and Botey clearly delineate the status of rural women in Mexico, and 
how their roles have changed over the last thirty five years. Their study does not, however, provide insight into the environmental situation in Mexico, although they discuss agricultural development. This study therefore provides excellent background material about the sociological status of women, and offers support to the environmental analysis this thesis will perform.

Anthropologist Lynne Stephen's analysis of rural Mexican women in Women in Mexico's Popular Movements, examines the effects on women of an ongoing economic and ecological crisis in Mexico (Stephen 1992). She reports that women are receiving little help from other family members, and ecological impoverishment exacerbates women's workloads. The gendered division of labor, already unequal in its distribution of work, generates heterogeneous reproductive responsibilities. Typically, women perform a much greater variety of tasks than do men, and fewer of them are compensated in money.

While few studies have counted the hours rural women work, Stephen's ethnographic accounts describe their day as beginning at 5 a.m. and finishing at 9 or 10 p.m. (Stephen 1992, 79). According to Stephen, women are exclusively responsible for all activities that contribute to the reproduction and maintenance of the family, including storing, preserving, processing, and preparing food; socializing and educating children; providing medical and psychological care; cleaning houses; washing; and hauling water and firewood, often from a long distance. Women may also be active in social community networks, maintaining a vital link among 
community households.

In order to accurately assess the economic situation in Mexico, Stephen offers a brief background of Mexico's economic development. Stephen describes the Mexican economy, with its emphasis and capital directed toward export commodities, as being characterized by a functional dualism (Stephen 1992, 73). In many areas of Mexico, a dominant capitalist export sector acquires a cheap labor supply by perpetuating and maintaining impoverished subsistence and informal sectors (Stephen $1992,73)$. The transformation of the agrarian economy earlier this century paid little heed to environmental concerns, and often disrupted the natural environment of rural families. Agrarian reform laws which seemingly aided rural farmers were ineffective due to the government's preoccupation with export luxury crops. Furthermore, national policies that drew capital from the rural sector to finance urban industrialization discouraged peasants from participating in their own agricultural production, encouraging rural families to buy their food on the open market.

After World War II, Mexico enjoyed rapid economic expansion and increased participation in the foreign market. Once touted as the country in Latin America most likely to become a "developed nation" (Stephen 1992, 74), Mexico's commercial agricultural sector was the primary source of domestic and foreign exchange. Stephen states that Mexico "saw its star decline in 1982 with the fall of oil prices " (Stephen $1992,74)$. Mexico's debt increased from $\$ 10$ billion in 1973 to $\$ 108$ billion in 1989 , and during the de la Madrid administration (1982-1988) inflation reached nearly 90 
percent and the economy averaged an annual growth rate in real gross domestic product of -4 percent (Stephen 1992, 74). The human costs of this ill economy are apparent in a 50 percent reduction in real minimum wages since 1982 and a 30 percent drop in the internal consumption of basic grains during the 1980s (Stephen 1992, 74).

The long term effects of the economic crisis and current plans to offer cheap labor and markets as enticements for foreign investment are distributed unevenly (Stephen 1992). Stephen asserts that the economic hardships caused by capital development have disproportionately fallen on rural women. Among the most dramatic changes which occurred in recent years was that of women's increased involvement in farming. While this can be partly explained by women's emergence into the paid agricultural sector, it may also be attributed to an increase of unwaged work on family farms. As men and children migrate in search of sufficient wages, women assume the increased work. While remittances from international migration have supplemented household income, if they are low or unreliable, women are left with the primary economic responsibility. Mexican women are receiving little help from husbands and children with domestic duties, yet they often subsidize insufficient male wages by extending their domestic duties of cooking, cleaning and washing (Stephen 1992).

Stephen's analysis is important in that she addresses some of the environmental problems faced by rural Mexican women, yet she describes them superficially and 
from an anthropological position. While she discusses the hardships caused by ecological degradation, she has no case studies to support her hypothesis and thus leaves open the necessity for case studies. Her work, like the study by Arizpe and Botey, provides good background information and literature support to the case studies this thesis will perform and analyze.

\section{Economic Crisis of the 1980s}

In Women and the World Economic Crisis, Jeanne Vickers (1991) explores the Mexican economic crisis that resulted in the 1980s. While much of her work outlines the events following the oil bust and offers less insight on its effects on women than the previous studies cited, Vickers' analysis is important in offering background on uneven development and the current rural economic situation. Furthermore, it offers support to the positions asserted earlier, specifically regarding the plight of agrarian communities in the midst of national economic decline.

According to Vickers, Mexico's discovery of oil in the 1970s laid the foundation for eminent economic catastrophe. During the oil boom (1980-81) speculation and inflationary pressures increased, and growth was due solely to foreign loans (Vickers 1991). Exacerbating the situation was a worldwide recession, deepened by spiraling interest rates, the fall in international demand for oil, and uncontrollable inflation. It is interesting however, that while federal funds for agriculture became less available, the government's spending on administration and defense increased from 17.6 percent to 52.6 percent during that time (Vickers 1991). 
Vickers asserts that the economic crisis hit Mexico's rural poor the hardest, as they were already suffering from undervalued crops and lack of government support due to a policy of uneven development that favored economic growth over social welfare. Between 1981 and 1986 the budget for agriculture declined in real terms by 50 percent (Vickers 1991). Government funding of agriculture continued to primarily support more profitable export crops. As a result, the production of basic grains for subsistence has been forced to move into zones where the weather is poor and productivity low, land dedicated to these crops has been reduced, and the rate of growth of agriculture has fallen (Vickers 1991).

Again, this study is important in that it provides background information necessary in understanding the current situation in rural Mexico. Vickers' economic analysis allows an interpretation of why rural villages have relocated to ecologically poor areas, and how the government contributed to the problem. Like the previous studies, this report does not sufficiently discuss the environmental problems encountered by rural women, and how those problems have impacted women's daily lives.

\section{Ecological Impoverishment in Mexico}

Several studies woven together offer a detailed description of Mexico's ecological condition. While it is possible to delineate these works singly, much of the information is repetitive and is best understood when integrally presented.

Fifty years after Mexico's agricultural revolution, the country remains in the 
throes of an ecological crisis. Earlier state-emphasized growth invested in environmentally damaging techniques, such as irrigation, agricultural uptake of marginal land, and pesticide application. Nuccio, Ornelas and Restrepo in their study Mexico's environment and the United States, assert the position that like many other countries, Mexico long ago set out on a development path that has accumulated greater and greater environmental deficits each year, while pushing them off onto future generations in hope that more wisdom would be available to those who followed (Nuccio, Ornelas and Restrepo 1990). Mexico's dependence on foreign capital led the country to intensify its exports in the 1960 s, the effects of which can be seen throughout the country.

Mexico has a rich natural endowment, but not necessarily one fully suited to the patterns of settlement and economic activity undertaken by modernizing Mexico (Nuccio, Ornelas and Restrepo 1990). Geographically, Mexico is both vast and varied. Its 1.97 million $\mathrm{km}^{2}$ make it the third largest nation in Latin America, after only Brazil and Argentina, and one of the 10 largest in the world (Levy and Szekely 1987). Once possessing an adequate agricultural base, today most of Mexico's agricultural land is mediocre at best. In the study entitled Sustainable development in Mexico, Goldrich and Carruthers estimate that about one-half of Mexico shows moderate to advanced erosion, and about one-fifth has already been destroyed (Goldrich and Carruthers 1992, 103), and Myers in Foreign Policy estimates that Mexico is losing over $2000 \mathrm{~km}^{2}$ per year to desertification (Myers 1989, 36). 
Deforestation. Tropical areas as well are falling victim to agriculture, as cattle ranching, coffee plantations and other croplands expand into forests. Nuccio et al. estimate that Mexico's current annual losses are approximately at $4000 \mathrm{~km}^{2}$ of a remaining 400,000 km² (Nuccio, Ornelas and Restrepo 1990, 26). Deforestation tends to be particularly heavy in southeastern Mexico, while development projects have ignored the fragility of tropical areas. Developers have followed a pattern of razing the forest and planting either monoculture crops, such as sugarcane or rice, that are ill-suited to the climate and soil conditions of the region, or establishing cattle ranching operations that damage the ecosystem (Nuccio, Ornelas and Restrepo 1990).

While agribusinesses are cultivating coffee and cattle, rural households suffer the loss of a vital resource--trees. In non-industrialized regions, Annabel Rodda (1991) citing a recent Food and Agriculture study, asserts that trees are inextricably woven into the rural and household economies. Trees are used to provide fuel, fodder and food; they supply medicines and shade, increased soil fertility, shelter from the wind and protection from the rain. Women, with the primary responsibility of collecting wood, are faced with the pressure of confronting scarcity. The cumulative, negative impacts of deforestation are plenty, with the main concerns being:

- As wood becomes increasingly scarce, women often travel long distances in search of forest materials, thereby adding hours to their already long working days (Rodda 1991, 83). 
- As more and more men find employment in the market sector and women are forced to assume their responsibilities, women have little time to devote to the collection of forest products (Rodda 1991, 84).

Without trees as a viable resource, women's abilities to provide food, medicine and other basic necessities to their families is threatened.

Water resources. Myers claims that water remains a main factor limiting agricultural productivity in two-thirds of Mexico's arable land (Myers 1989, 35). While surface waters are scarce, those that do exist are far from the areas of major water demand or are located at elevations that require significant transport (Nuccio, Ornelas and Restrepo 1990). All five of Mexico's principal rivers--totalling more than 50 percent of the mean annual flow of all Mexican rivers--are located in the tropical southeastern part of the country (Nuccio, Ornelas and Restrepo 1990, 27). A disproportionate amount of the population and industry are located at elevations above 1000 meters, while 85 percent of Mexico's water resources are located in areas of less than 500 meters in elevation (Nuccio, Ornelas and Restrepo 1990, 27). Failing water ability and soil erosion have led to the abandonment of about $1000 \mathrm{~km}^{2}$ of farmland each year, affecting both large-scale farmers and peasants alike (Myers 1989, 36).

While a water shortage exists for Mexico's agricultural sector, a water crisis ensues for rural households. Water is needed by the family for drinking, domestic purposes, personal hygiene and sanitation, as well as for uses on the farm (Rodda 
1991, 51). If families engage in the selling of farm products, water becomes a vital economic resource as well. As with fuelwood, women are responsible for collecting water and controlling its use. Not only is water scarcity a problem, but access to clean water sources is an increasingly difficult prospect. The importance of water quality for health is clear: most human diseases are transmitted by water, such as cholera, typhoid and infectious hepatitis, or are otherwise water related (Dankelman and Davidson 1989, 32). Water problems for women therefore, are twofold as they must maintain access to an adequate water supply while ensuring the safety standards of its use. In times of dire need, or when women are unaware of contamination, women use polluted water out of sheer necessity.

Pesticides. Pesticide contamination in Mexico further exacerbates the water crisis. Peasant agricultural workers often live on small plots of land between plantations and irrigation canals that collect pesticide runoff. In addition to washing their children, dishes and clothes in the canals, Nuccio et al. report that women fill discarded insecticide tubs with contaminated water from the canals for drinking purposes (Nuccio, Ornelas and Restrepo 1990).

Furthermore, pesticides pose a serious threat to the lives of rural farmworkers. In The Death of Ramon Gonzales, a comprehensive study on pesticide use in Mexico, Angus Wright (1992) states that crops are routinely sprayed with substances known to cause, in addition to immediate poisoning symptoms ranging from dermatitis to death, severe respiratory ailments, long-term nerve damage, blindness, mental disturbances, 
birth defects, abortions, leukemia, anemia, and a variety of cancers (Wright 1992). Entire peasant families are subject to the atrocities of pesticide application, with women responsible for tending to the sick.

All of these studies are excellent in describing the environmental crisis in Mexico, yet none relate specifically to the effect on rural women. For this thesis in particular, the sections on deforestation and water resources provide excellent background information from which this thesis will build. A synthesis of the studies on rural women and environmental degradation provide an area where actual case studies are necessary to examine the relationship between women and the environment.

Women and Development in Mexico

Ponna Wignaraja (1990), in Women, Poverty and Resources, outlines new types of development programs for women in Latin America. She attributes the burden poor Latin women suffer to:

extremely skewed land and ownership patterns, modernization strategies in the agricultural sector, migration of younger persons to urban areas and across the borders, ....the cultural undervaluation of their work and contribution to society, and their continued exploitation (Wignaraja 1990, 167).

Furthermore, lack of access to lending institutions like the Rural Development Bank exacerbates poor women's unequal status. In other words, uneven development is responsible for creating rural hardships, both generally for all rural peasants and in ways that affect only women. 
Wignaraja states that internal reviews initiated by development donor programs for women in Latin America have revealed that "there were too many scattered activities, mainly meetings" (Wignaraja 1990, 168). Each donor supported up to twenty different kinds of activities involving health education, appropriate technology, income generating projects, urban coalitions, and rural groups (Wignaraja 1990, 168). Funds were often diluted and programs were not always offered to the poorest sector of women.

In Mexico specifically, Wignaraja examines the role of non-governmental organizations (NGOs) in development issues. She tracks the progress of one group in particular, Promocion del Desarrollo Popular (PDP), and their experimentation for bringing poor women out of poverty into sustainable development (Wignaraja 1990, 176). PDP's leadership is consisted of a group of twenty facilitators and actionresearchers who function as participatory mini-teams in various locations (Wignaraja 1990, 178). PDP collaborates with local grassroots groups and other involved NGOs, which provides a broad-based network with a varying degree of resources. While Wignaraja does not outline the objectives of PDP or its criteria for helping women, she cites its success in building a coalition with other NGOs by offering support at many levels.

Wignaraja's work is important in that it shows that there are organizations in Mexico that are working toward sustainability with women. She does not however discuss the previous environmental situation faced by the women who participated in 
this alternative development. Again, case studies concerning women who have been negatively affected by environmental degradation would provide examples to discuss the appropriateness of sustainable development. This thesis will provide those case studies, and allow an illustration of the types of communities most in need.

\section{A Representative Model of Women and Development}

The problems encountered by rural Mexican women are not unique; in fact, they suffer the same burden as many other Third World women. Examining the problems, responses, and commonalities among poor rural women worldwide enables an analysis and extrapolation of the lessons learned in other areas. Both an ideological conceptualization and the actual material reality encountered by Third World women are germane in this discussion, and require analysis in order to present relevant background information.

Theoretical framework. The relationship between women and the environment has fostered lively debate and academic discussion, as sociology and anthropology have popularized the growing literature on women and natural resource management. The notion that women in poor rural households are victims of environmental degradation in gender-specific ways is now widely accepted, and women's roles as active agents of change within the environmental movement is likewise recognized. Ecofeminism explains this relationship by conceptualizing the link between gender and the environment primarily in ideological terms (Agarwal 1992). While ecofeminism is a growing body of thought, several arguments outline its basic precepts (King 1981; 
King 1989; Merchant 1980; Zimmerman 1987):

- There are important connections between the domination and oppression of women and the domination and exploitation of nature

- Women are identified as being closer to nature, and men as being closer to culture. Because nature is seen as inferior to culture; hence, women are seen as inferior to men

- Because the domination of women and the domination of nature have occurred together, women have a particular interest in ending the domination of nature

- The feminist movement and the environmental movement both stand for egalitarian, post-patriarchal systems. Thus they have a good deal in common and need to combine efforts to evolve a common perspective, theory, and practice.

The ecofeminist connection between the domination of women and that of nature is primarily ideological, rooted in a system of ideas and representations, values and beliefs, that places women and the nonhuman world hierarchically below men (Agarwal 1992, 120). The idea that women are seen as closer to nature than men has been criticized, specifically by attacking the nature-culture dichotomy as a false patriarchal ideological construct which is used to maintain gender hierarchy (Merchant 1980, 144). Ecofeminist discourse however, highlights the important conceptual links between the symbolic construction of women and nature, and is aware of the commonality between the premises of the environmental and women's movement, while valuing an alternative vision of a more egalitarian and harmonious future society. These inherent ideologies therefore, seem to forge a solid relationship between feminism and environmentalism.

The ecofeminist argument is problematic however, as it posits women as a 
unitary category and fails to differentiate among women by class, race, and ethnicity, and thus ignores forms of domination other than gender which also hinder women (Agarwal 1992; King 1981). According to feminist scholar Bina Agarwal, ecofeminism also recognizes the domination over women and nature solely in ideological terms, neglecting the interrelated material sources of this dominance based on economic advantage and political power (Agarwal 1992, 122). Furthermore, ecofeminism fails to take into account women's material relationship with nature, as opposed to what others conceive that relationship to be.

Vandana Shiva agrees with ecofeminists that violence against nature and against women is built into the very mode of perceiving both, but takes a step forward in recognizing that violence against nature is intrinsic to the dominant industrial/developmental model. At the same time, Shiva stresses that violence against women and nature is linked not only ideologically, but also materially (Shiva 1988). For instance, Third World women are dependent upon nature for sustaining themselves and their families. The destruction of nature thus becomes the destruction of women's sources for staying alive (Shiva 1988; Agarwal 1992). Drawing upon her experiences of working with women activists in the Chipko movement, Shiva argues that Third World women have a dependence on nature and a knowledge of it. According to Shiva, this knowledge has been systematically marginalized under the impact of modern science:

Modern reductionist science, like development, turns out to be a patriarchal 
project, which has excluded women as experts, and has simultaneously excluded ecology and holistic ways of knowing which understand and respect nature's processes and interconnectedness as science (Shiva 1988, 14).

In order to address the concerns expressed by Vandana Shiva, Bina Agarwal suggests using the term feminist environmentalism to understand the human relationship with nature as rooted in material reality, i.e., the specific forms of interaction with the environment. According to Agarwal, while there is a gender and class-based division of labor and distribution of property and power, gender and class also structure people's interactions with nature and so structure the effects of environmental change on people and their responses to it (Agarwal 1992, 126). For instance, poor peasant women are typically responsible for fetching fuelwood, and thus likely to be affected adversely in specific ways by environmental degradation. At the same time, in the course of their interactions with nature, they acquire a special knowledge of species varieties and the processes of natural regeneration. They can therefore be seen as both victims of environmental destruction, and as repositories of knowledge about nature, in ways distinct from the men of their class. According to Agarwal, the former aspect would provide the gendered impulse for their resistance and response to environmental degradation. The latter would condition their perceptions and choices of what should be done (Agarwal 1992, 127). Based on their experiential understanding of nature, women could provide a special perspective on the process of environmental regeneration, and thereby influence alternative approaches to development. 
In terms of what actions shouid be taken to promote a feminist environmental agenda, such a perspective calls for struggles over both resources and meanings. A transformation of power and property structure would be necessary in order gain control of resources. On the feminist front, there should be a need to challenge and transform both notions about gender and the actual division of work and resources between the sexes (Agarwal 1992). Environmentally, the relationship between humans and the environment would need to be understood, and the methods of fair allocation of resources would need to be developed. Feminist environmentalism underlines the necessity of addressing these dimensions and holistically challenging environmental degradation.

The issue of women and development is better understood and more accepted in India and African countries as compared to Latin America, mainly because the bulk of research has focused on those areas. Because Mexico is similar to other Third World countries in terms of environmental degradation, economics, and gender stratification, it is prudent to consult successful endeavors in other areas. Through careful planning and insightful leadership, women should be involved in development initiatives, and in fact, their involvement may not only spur economic gain, but increase environmental conservation simultaneously. The current representative models of women and development offer encouragement and hope to poor women everywhere. Perhaps if more leaders embrace the notion of environmental feminism and study its effects, they can pursue both development and conservation. In the next 
decade, NAFTA and other trade accords will force Mexico to develop quickly. If Mexico hopes to incorporate its poor and raise the standard of living among peasants, it must learn from alternative development models and accept women into planning and development initiatives.

\section{Conclusion}

This literature review elucidates various assumptions concerning the relationship between rural Mexican women and natural resource scarcity. In answering how women are affected by wood and water shortages and how women are responding, we must first clearly understand several components. First, the relationship between rural women and work must be clear along with evidence of a gendered division of labor. Arizpe and Botey and Stephen outline women's relationship to resource use and delineate the division of labor common in rural societies. We can incorporate this assumption and build upon it as the underlying component in answering the research questions.

The next assumption that needs support is that Mexico's policies of uneven development have hurt rural peasants. This assumption puts the peasants' current economic and resource conditions in context, i.e., how the people have become entrenched in poverty and constant need. Stephen touches upon this issue, specifically relating it to women, and Vickers offers an overall summary of the government's policies and their subsequent ramifications.

The third assumption is that ecological impoverishment in Mexico is 
widespread. In order to accept the problems of deforestation and water shortages in rural Oaxaca, it is necessary to offer factual evidence of these processes. The studies woven together in this literature review document the environmental problems faced by Mexico as a whole. From this we can extrapolate to Oaxaca and combine the earlier assumptions relating to women and the environment to accept that deforestation and water scarcity are pressing issues for rural women.

The fourth assumption is that appropriate development for women in Mexico is realistic. In examining how Oaxacan women are affected by ecological impoverishment, it is natural to ponder solutions. Wignaraja explains why past development has hurt women and outlines new successful projects in Mexico. By understanding that viable alternatives of uneven and inappropriate development exist, it makes the results of this thesis crucial in formulating a solution.

The last assumption is that a model supporting these ideas exists and offers a way to rethink how women and the environment should be treated. Agarwal presents feminist environmentalism as a means of understanding women's interactions with the environment. This thesis is guided by the feminist environmentalism model in that it seeks to understand women as both victims of environmental destruction and as agents of environmental restoration.

By building upon these assumptions, this thesis is supported by a conceptual and theoretical framework that provides excellent background information necessary in understanding the complex relationship between environmental degradation and 
women's work. None of the works presented however weave together the many facets surrounding the relationship of women and the environment. This thesis holistically integrates these assumptions in order to understand how ecological deterioration specifically affects women in three rural Mexican villages. With the background information in mind we can now analyze how women are affected by water and wood scarcity, in what ways they are responding to these shortages, and what the implications are of this complex relationship. This documentation will not only specifically address women in Oaxaca, but will generalize out and contribute to the knowledge of how women are victims of environmental impoverishment and what can be done to mitigate the ramifications. In order to effectively examine these issues, this thesis adheres to a non-conventional methodology that stresses the principles of feminist environmentalism. 


\section{CHAPTER 3 \\ THE FEMINIST PERSPECTIVE AND THE RESEARCH DESIGN}

The research design is guided by a non-conventional methodology that is referred to as a feminist perspective. The feminist perspective describes the basic philosophy and methods commonly used in a non-conventional design and offers a framework to guide holistic studies focusing on women's issues. While the notion of a feminist perspective is mostly found in sociological literature, its broad approach to research makes it pertinent to this cross-disciplined thesis. This thesis examines the lives of rural women, their social systems, and their natural environment, and is not confined to one discipline, but rather incorporates the fields of anthropology, sociology, ecology, and geography. A feminist perspective successfully integrates the model of feminist environmentalism by stressing the importance of analyzing women and their experiential relationships. Furthermore, the feminist perspective stresses the importance of understanding women's stories and views the research process as an exploratory path open to change (Geiger 1992, 306).

The holistic scope, along with the nature of the study makes it appropriate to incorporate subjectivity and invites inductive logic in order to assemble a meaningful analysis. This thesis explores the consequences of resource depletion on rural Oaxacan women and is more interested in their subjective beliefs than in the statistical 
depletion rates; how the women perceive their situation is more important than the actual rates of deforestation and drought because their behaviors are controlled by their perceptions and assumptions. Conventional scientific methods however, stress rigidity in the form of hypothesis testing and deductive logic. Therefore, in order to incorporate the many disciplines involved, and in order to encourage subjective analysis, this thesis supports the principles of a feminist perspective.

This thesis employs case studies to examine women and their relationship to the environment. Case studies are popular in feminist research for three reasons. According to Shulamit Reinharz, case studies analyze the change in phenomenon over time, analyze the significance of a phenomenon for future events, and analyze the relation among parts of a phenomenon (164). Reinharz (1992) also explains that case studies should be used as a tool to document history and generate theory (174).

The underlying assumption of a feminist perspective is that methods and methodology are not simply techniques and rationales for the conduct of research; rather they must be understood in relation to specific historical, cultural, and ideological contexts (Reinharz 1983, 162). The following sections examine the concept of a feminist perspective by examining its practice in research and its underlying epistimological roots and explain its relevance to this study. Principles of the Feminist Perspective

The following represents Cook and Fonow's (1986) five basic principles that run throughout analysis of feminist epistemology. They include: Acknowledging the 
influence of gender; focusing on consciousness-raising; a rejection of the subject/object separation; examination of ethical concerns; and emphasis on empowerment and transformation.

(1) Acknowledging the influence of gender as a basic fact of social life involves several factors. First, women and their experiences are the focus of inquiry, and thus investigations employing a feminist perspective view women through a "female prism" in research dedicated to analyzing and interpreting the female world (Cook and Fonow 1986). Often times these investigations occur within a personal sphere that has actually been experienced. Feminist methodology therefore values the subjective and seeks to validate the private intimate world.

A second aspect of this principle involves the recognition that much of what is considered knowledge about human behavior is in fact knowledge about male behavior (Cook and Fonow 1986). By equating the masculine with the universal, such unexamined assumptions regarding scientific objectivity often serve to obscure patriarchal bias at the very essence of science (Cook 1983). Academic discourse therefore, may be characterized as a male discourse hidden behind the labels of science, rationality, and scholarship (Cook 1983).

The third idea important in attending to gender is to identify the researcher as a gendered being in the web of social relations that simultaneously influences the analytical and interpretive procedures of research and shapes the life experiences of the researcher (Cook and Fonow 1986). The feminist researcher is then able to locate 
herself as a subject in history, so that her own experiences are pertinent in analyzing the data. Understanding the biases and viewpoints of the female researcher, and allowing her to conceptualize her common experiences with the women subjects, offers a degree of depth in which the researcher can bring women's realities into sharper focus.

This first tenet is important in this study in that it acknowledges the importance of focusing on women subjects. Much ethnographic and geographic data on Oaxaca concentrates on the male perspective or offers a general analysis of rural life, focusing on neither women nor men. However, the social structure of the peasant community is governed by discrete gender roles making it necessary to understand each gender group separately before a general analysis can be made.

This study is concerned with women for several reasons. First, women are the primary caretakers and the hindrance of their tasks affects the family's ability to survive and, by extension, their entire community. Secondly, the women in La Cumbre, San Mateo, and El Carrizal have direct contact with wood and water and therefore know details concerning changes in the levels of these resources. Thirdly, the women studied are responsible for both collecting water and wood and they are affected by shortages before other community members. The women work harder in response to the lack of wood and water, and it is only after they can no longer compensate for the shortages that other family members feel the effects of resource scarcity. 
(2) The concept of consciousness-raising is a central tenet of feminist

perspective in a variety of ways. First, a researcher's feminist consciousness can serve as a source of knowledge and insight into wider asymmetry and how it is managed in social life (Cook and Fonow 1986). Feminist scholars inhabit the world with a double vision of reality, which enables them to penetrate official interpretations of reality and apprehend contrary forces simultaneously (Cook and Fonow 1986). At the methodological level, an awareness of the double consciousness that arises from being a member of the oppressed class (women) and a privileged class (scholars) enables feminist researchers to explore women's perceptions of their situations from an experiential base (Reinharz 1983). According to Cook and Fonow,

Because women and other exploited groups are forced, out of selfpreservation, to know the motives of their oppressors as well as how oppression and exploitation feel to the victims, they are better equipped to comprehend and interpret women's experiences $(1986,12)$.

Scholars who understand this principle are in a better position to understand the varied responses to oppression. According to Westkott (1983) research methods that overemphasize quantification force the researcher to pose structural questions about action while ignoring the subjective dimension of behavior, as well as contradictions between action and consciousness. This approach ignores the fact that many women simultaneously oppose and conform to conditions that hinder their freedom (Cook and Fonow 1986). Through a sphere of consciousness, women are able to imagine a freedom which is behaviorally denied to them. According to Westkott, 
consciousness can be viewed as women's sphere of freedom, a sphere that exists simultaneously with unfree, conforming behavior, so that methodological over reliance on recording and failure to tap the private terrain of consciousness neglects the most important area of women's creative expression of self in a society which denies that freedom in behavior (Westkott 1983, 429).

Finally, the process of conscientization combines consciousness-raising and social change through encouraging politicization and activism on the part of the research subjects (Cook and Fonow 1986). In the process of research, the subjects learn to perceive social, political, and economic contradictions (Mies 1983). The subjects are therefore motivated to take action against the oppressive elements of reality, and the outcome of the research, apart from what the researcher gains, is a greater sense of awareness among subjects leading to social change (Mies 1983, 126).

The gender of the researcher is relevant to this study for several reasons. Although the researcher is culturaliy different from the women studied, her gender provides some insight into understanding the components and obstacles faced by women in general. Furthermore, the women subjects were more likely open with the researcher because of her gender: In a culture often segregated by gender, it is assumed that the women feel more comfortable relating sex-specific topics with a woman researcher than with a male researcher. Therefore, it is assumed that the responses were more honest, candid, and insightful because of the gender of the researcher.

(3) The rejection of the rigid dichotomy of subject and object has led 
researchers to investigate ways in which to bridge the hierarchical gap (Cook and Fonow 1986). Feminists have explored the belief that strict separation of the researcher and subject produces more valid, legitimate knowledge. Epistemologically, feminist scholars reject this notion and favor a more participatory research strategy that emphasizes the dialectic between researcher and subject throughout the research process (Cook and Fonow 1986). Mies (1983) calls for a shift from a vertical relationship between the research and subject, to a horizontal, more equal relationship. The researcher's understanding of her connection and relationship to the experiences of the research subject through partial identification is labeled "conscious partiality" by Mies and enables her to replace "spectator knowledge," which emphasizes neutrality and indifference toward subjects (Mies 1983, 124).

Feminist researchers have examined ways in which the research process obscures and reinforces the subordination of women participants at every level (Cook and Fonow 1986). According to Smith (1979), feminists are able to understand how sociological methods conceal social relations between the researcher and the object. As researchers try to include women as subjects, they also realize that the practice of sociology transforms all those involved into objects. Smith says,

as women we become objects to ourselves as subjects. We ourselves, therefore, can look back as subjects constituted as objects in that relation, and in doing so, we disclose its essential contradiction (Smith 1979, 159).

According to Cook and Fonow (1986), feminist consciousness of the link between the knower and subject can not only 
serve to demystify objectivity and the objectification of women, but also extends our understanding of how the exploitations of women as data mirrors the treatment of women who contribute their specific skills and expertise to the research enterprise $(1986,15)$.

Feminists have also criticized the tendency to equate measurement of quantification with objectivity (Cook and Fonow 1986). They point out that quantification has its own inherent biases and distortions. For instance, Pagelow (1979) points out that current emphasis on statistical methods means that variables are often conceptualized according to what is most easily quantifiable rather than what is most theoretically important. Ann and Robin Oakley (1979) note the necessity of distinguishing between the processes producing actual behavior and the processes producing statistics, because these are separate phenomena requiring different interpretations.

The analysis of this thesis is guided by this principle. In analyzing how women's lives are affected by a resource shortage and how they have responded to the shortage, the women's opinions are carefully recorded, yet the analysis relies on a subjective translation. The Oaxacan women are not seen as objects with measurable responses, but rather their answers are subjectively analyzed and their beliefs and emotions are incorporated into the discourse of the results. Treating the women as data would only serve to objectify personal responses and eliminate key components of understanding and interpretation. Statistical analysis would merely bury the feeling of the results, which is important to present due to the personal nature of the study. 
In this thesis, treating women as people with valuable experience yielded insight into the many complexities of their lives.

(4) A Feminist perspective involves a concern with ethical issues that arise when feminists participate in the research process (Cook and Fonow 1986). Feminist researchers are careful of using language as a means of subordination, such as using masculine pronouns, applying offensive adjectives to women's experiences, and subsuming women under male categories (see The Nebraska Sociological Feminist Collective 1982). Furthermore, according to Cook and Fonow (1986), a feminist ethic requires investigation into professional gatekeeping practices, particularly those which prevent publication and dissemination of feminist research through mainstream channels. For feminist researchers, anticipating the consequences of research for the subjects and the potential ethical issues involved are problematic, and more attention to the development of a feminist ethic is being initiated (Cook and Fonow 1986).

The interviewing procedure and questionnaires used in this study were carefully guided by this principle. The women were interviewed in their familiar surroundings so that they would be comfortable and less intimidated. In La Cumbre and San Mateo, the women were interviewed in a communal meeting room, and in $\mathrm{El}$ Carrizal the interview was conducted outside near the farm plots. Furthermore, the language of the questions reflected a knowledge of female roles. For example, the researcher asked specifically about certain female tasks, such as taking care of the family, and was careful to focus on topics of interest to the women. This was 
important because it developed a bond that made the women feel comfortable with the interview and therefore improved the credibility of the responses.

(5) Lastly, an assumption of feminist methodology is that knowledge must be elicited and analyzed in a way that can be used by women to alter oppressive and exploitative conditions (Cook and Fonow 1986). According to Cook and Fonow, this means that research must be designed to provide a vision of the future as well as a structural picture of the present. This goal involves attending to the policy implications of an inquiry, and may involve incorporating the potential target group in the design and execution of a study (Cook and Fonow 1986, 17).

Feminist methodology endorses the assumptions that the most thorough kind of knowledge and understanding comes through efforts to change social phenomena. Cook and Fonow assert that "feminist research is...not research about women but research for women to be used in transforming a sexist society" $(1986,18)$.

This last guideline expresses the hopes of the researcher, in that this stidy may be used to alleviate rural women's burdens and mitigate environmental problems by calling attention to the plight of Oaxacan peasants. Without information and studies specifically highlighting the rural situation, Mexican peasants will continue to struggle for survival.

This thesis adheres to the principles of a feminist methodology and attempts to holistically integrate the data, archival research, and current geographical and anthropological philosophy. In addition to the principles outlined above, much of the ecological information was recorded through non-conventional methods. The 
researcher's observation and the women's personal testimonies are offered as evidence of environmental deterioration. Because this study deals with the consequences of wood and water scarcity, it is unnecessary to focus on mathematical rates of depletion or other measurable changes. It is important to record how the women perceive the environmental situation and how they feel it has affected them, because they are responsible for collecting the resources. This thesis is concerned with the women's attitudes and beliefs, rather than scientific figures.

Various assumptions exist in the traditional science method that are too confining for the broad purposes of this study such as hypothesis testing and scientific analysis; the feminist perspective that guided the methodology and underlying philosophies are therefore believed to be more representative in this case. To highlight the differences between conventional and feminist research, Table 2 contrasts the traditional or patriarchal method with the feminist method.

Design

The design of this thesis was guided by a one-group post-test only design, where a single group of individuals is measured on a dependent variable (women's work loads) after an intervention has taken place (environmental degradation). This type of design is most often used in analyzing change in rural societies (Bernard 1988). This thesis was guided by a natural experiment philosophy, in which natural events are evaluated and interpreted. This project examined the phenomenon that links increased environmental degradation with increased work loads for women. It 
was difficult to control validity in this experiment, due to the impressionistic nature of it. The threats to validity include: 1) history confound, in which other historical causes may have contributed to the problem of increasing women's work loads. In order to account for this threat to validity, the women involved were thoroughly questioned in order to account for other explanations; 2) selection bias, where there is no control over who is assigned to be interviewed. That is, because there was not a random pool of individuals interviewed, the sample examined may simply experience higher work burdens than a statistical average of the population. In order to increase validity in nonprobablility sampling, this thesis incorporates original data with ethnographic studies concerning the same types of women (see Chapter 2). Ethnographic studies can provide information on the amount of time spent on tasks, and what changes have historically occurred. When coupled with ethnographic data, nonprobability sampling has high credibility (Bernard 1988).

\section{Population sample}

In the three villages studied, a total of forty two women were interviewed, fifteen in both La Cumbre and El Carrizal and twelve in San Mateo. The women were chosen to be interviewed because they were in the village at the time the interviewer arrived, and all expressed a willingness to participate. All interviews were conducted in groups. The women's ages ranged from 18 to 47 . 
TABLE 2

CONTEMPORARY RESEARCH MODELS

\begin{tabular}{||l|l|l||}
\hline & $\begin{array}{l}\text { Conventional or } \\
\text { Patriarchal }\end{array}$ & Alternative or Feminist \\
\hline Units of study & $\begin{array}{l}\text { Predefined, } \\
\text { operationalized concepts } \\
\text { stated as hypothesis }\end{array}$ & $\begin{array}{l}\text { Natural events encased in } \\
\text { their ongoing contexts }\end{array}$ \\
\hline Sharpness of focus & $\begin{array}{l}\text { Limited, specialized, } \\
\text { specific, elusive }\end{array}$ & Broad, inclusive \\
\hline Data type & Statistical, factual & Factual, insightful \\
\hline Topic of study & $\begin{array}{l}\text { Manageable issue derived } \\
\text { from scholarly literature, } \\
\text { selected for potential } \\
\text { scholarly contribution, } \\
\text { sometimes socially } \\
\text { significant }\end{array}$ & $\begin{array}{l}\text { Socially significant } \\
\text { problem sometimes } \\
\text { related to issues } \\
\text { discussed in scholarly } \\
\text { literature }\end{array}$ \\
\hline $\begin{array}{l}\text { Role of research: } \\
\text { in relation to } \\
\text { environment }\end{array}$ & $\begin{array}{l}\text { Control of environment is } \\
\text { desired, attempt to } \\
\text { manage research } \\
\text { conditions }\end{array}$ & $\begin{array}{l}\text { Openness to } \\
\text { environment, immersion, } \\
\text { being subject to and } \\
\text { shaped by it }\end{array}$ \\
\hline $\begin{array}{l}\text { Role of research: } \\
\text { in relation to subjects }\end{array}$ & Detached & $\begin{array}{l}\text { Involved, sense of } \\
\text { commitment, } \\
\text { participation }\end{array}$ \\
\hline $\begin{array}{l}\text { Role of research: } \\
\text { as a person }\end{array}$ & $\begin{array}{l}\text { Relevant, expected to } \\
\text { change during process }\end{array}$ \\
\hline $\begin{array}{l}\text { Role of research: } \\
\text { impact of researcher }\end{array}$ & Irrelevant & $\begin{array}{l}\text { Anticipated, recorded, } \\
\text { reported, valued }\end{array}$ \\
\hline $\begin{array}{l}\text { Implementation of } \\
\text { method }\end{array}$ & $\begin{array}{l}\text { As per design, decided a } \\
\text { priori }\end{array}$ & $\begin{array}{l}\text { Method determined by } \\
\text { unique characteristics of } \\
\text { field setting }\end{array}$ \\
\hline
\end{tabular}


TABLE 2--Continued

\begin{tabular}{||l|l|l||}
\hline & $\begin{array}{l}\text { Conventional or } \\
\text { patriarchal }\end{array}$ & Alternative or feminist \\
\hline Validity criteria & $\begin{array}{l}\text { Proof, evidence, } \\
\text { statistical significance; } \\
\text { study must be replicable } \\
\text { and yield same results to } \\
\text { have valid findings }\end{array}$ & $\begin{array}{l}\text { Completeness, } \\
\text { plausibility, } \\
\text { illustrativeness, } \\
\text { understanding, } \\
\text { responsive to subjects' } \\
\text { experience; study cannot } \\
\text { be replicated }\end{array}$ \\
\hline The role of theory & $\begin{array}{l}\text { Crucial as determinant of } \\
\text { research design }\end{array}$ & $\begin{array}{l}\text { Emerges from research } \\
\text { implementation }\end{array}$ \\
\hline Data analysis & $\begin{array}{l}\text { Arranged in advance } \\
\text { relying on deductive } \\
\text { logic, done when all data } \\
\text { are "in" }\end{array}$ & $\begin{array}{l}\text { Done during the study, } \\
\text { relying on inductive logic }\end{array}$ \\
\hline Manipulation of data & $\begin{array}{l}\text { Utilization of statistical } \\
\text { analysis }\end{array}$ & $\begin{array}{l}\text { Creation of meaningful } \\
\text { patterns }\end{array}$ \\
\hline Research objectives & $\begin{array}{l}\text { Testing hypothesis } \\
\text { Revelopment of } \\
\text { understanding through } \\
\text { grounded concepts and } \\
\text { descriptions }\end{array}$ \\
\hline Values & $\begin{array}{l}\text { Researcher's attitudes not } \\
\text { revealed, recognized or } \\
\text { analyzed, attempts to be } \\
\text { value-free, objective }\end{array}$ & $\begin{array}{l}\text { Researcher's attitudes } \\
\text { described and discussed, } \\
\text { values acknowledged, } \\
\text { revealed }\end{array}$ \\
\hline $\begin{array}{l}\text { Scholarly community } \\
\text { addressed, evaluation of } \\
\text { research design, } \\
\text { management, and findings }\end{array}$ & $\begin{array}{l}\text { Scholarly and user } \\
\text { community addressed and } \\
\text { engaged; evaluate } \\
\text { usefulness and } \\
\text { responsiveness to } \\
\text { perceived needs }\end{array}$ \\
\hline
\end{tabular}

Source: Adapted from Shulamit Reinharz, Experiential analysis. In G. Bowles and R. Klein (eds.) Theories of Women's Studies. (London: Routledge and Kegan Paul, 1983), 170-172. 


\section{Data collection}

The data collection process centered around the need to incorporate many different data sources, in order to confirm the validity and reliability of the original research conducted. The original data obtained was collected over a five week period in the Summer of 1993. Several visits were made to the three villages, La Cumbre, San Mateo, and El Carrizal. Interviews were also conducted with a female social worker from La Programa de Apoyo para a Desarrollo de la Mujer (Development and Support Program for Women), and the Coordinator from Sistema para el Desarrollo Integral de la Familia del Estado de Oaxaca (Family Development Agency) in Oaxaca, Oaxaca. In addition, informational materials were obtained at the Women's Center in Oaxaca, where there is a library with extensive information on environmental and women's issues. This archival data was used as initial background material to determine the existence of a problem connecting resource scarcity with heavy burdens on women. Additional material was collected at a conference on women in Oaxaca held at the Women's Center.

Information on environmental conditions was obtained through various archival resources (see References), interviews with the social worker (who works primarily in rural areas where the people are dependent on natural resources), interviews with women in the villages, and personal observations. Deforestation and erosion are obvious and visible throughout the surrounding areas. A description of environmental conditions in the valley of Oaxaca is also included in the introductory chapter (see 
Chapter 1).

It was difficult to find specific social and environmental data on the area surveyed, mainly because little data exists. The social worker from La Programa de Apoyo para a Desarrollo de la Mujer is currently part of an initial research team gathering information on the surrounding rural communities and their living conditions. The data collected for this thesis will contribute to the pool of information being compiled.

The women in the villages were all asked the same questions from a questionnaire developed by the researcher (Fig. 7). The interviews took place in the presence of the social worker, who accompanied the researcher to all of the sites. The women interviewed were chosen because they were willing to take a break from their schedules in order to be interviewed. The interviews were conducted to the groups as a whole, and each woman was allowed a chance to speak. No one refused to be interviewed. All interviews were tape recorded.

After the data was collected, it was coded for similarities and thematic patterns. This analysis will be presented in Chapter 4. Several demographic questions still remained after the initial coding process, which were answered through further interviews with the social worker, and did not warrant a return visit to the individual villages.

\section{Conclusion}

This study is interested in the subjective experience of rural Oaxacan women 


\section{Questionnaire}

1) Please describe your daily work schedule.

Probes: When do you wake up? When do you go to sleep? What are all of your responsibilities?

2) Who collects fuelwood?

3) Who collects water?

4) Are your work loads different than they were five years ago? How so?

5) Describe the economic conditions of your village?

Probes: Are you self-sufficient or do you engage in wage labor? is there migration from your village?

6) Has there been a change in fuelwood/water levels over the last few years? If so, is there more or less wood/water available?

7) How does this affect you?

8) If you could request any type of development services, what would you request?

Figure 7. Data Questionnaire

and therefore uses a feminist perspective in assembling the data and presenting an analysis. Five basic feminist principles were followed throughout this study. They are: Acknowledging the influence of gender as a basic fact of social life; incorporating consciousness-raising as central tenet of the study; the rejection of the rigid dichotomy of subject and object; the concern with ethical issues that arise during 
the course of study; and the assumption that knowledge must be elicited and analyzed in a way that can be used by women to alter oppressive and exploitative conditions. Following these guidelines facilitated the formulation of the research design.

The design of this thesis was guided by a one-group post-test only design. The study is directed by a natural experiment philosophy in which natural events are evaluated and interpreted. The interview questions were carefully worded to reduce validity and reliability errors, and to alleviate any gender bias in the interviewing process. The data was collected over a five week period in which a total of forty two women were interviewed. The following data was recorded using the tenets of the feminist model explained above. 


\section{CHAPTER 4}

\section{THE WOMEN SPEAK}

This chapter summarizes the data and begins answering the questions: How are rural Oaxacan women's lives affected by resource scarcity and how do women respond to the ensuing resource shortage? In answering these questions the following issues were addressed:

- Is fuelwood/water increasing or decreasing in the villages?

- Are women spending more time collecting wood/water?

- Do the women perceive their burdens as being heavier?

- Have any development projects occurred in response to these issues?

- If so, are they perceived as successful?

- Is there a difference in these patterns among villages?

By addressing these linear questions it is possible to substantiate the larger concerns and begin assembling a holistic analysis which places the context of this thesis into a larger realm.

\section{$\underline{\text { La Cumbre }}$}

The first village visited was La Cumbre, situated on a plateau along the southwest edge of the Valley of Oaxaca, in the district of Zimatlan. La Cumbre is surrounded by a coniferous forest, with visible signs of deforestation (Figs. 8 and 9). Along the hillsides there are deep fissures caused by soil erosion that seem to bisect family plots. The village itself was once covered with trees, but is now a deforested 
peak carpeted with grass. Sheep and goats roam the farms, which also contribute to erosion as they eat away the grass. The weather is often cold and wet which creates runoff and exacerbates the erosion process.

La Cumbre has a total population of 324 people, with 151 men and 173 women. Residents are mestizos, a mixture of indigenous and Latino backgrounds. While the road leading from the city of Oaxaca to La Cumbre is difficult and arduous, the distance to the city is only $35 \mathrm{~km}$. La Cumbre has existed for at least 15 years, and is currently supported by piped water, electricity, a school, and medical services. Although there is piped water, most houses do not have bathrooms. The most common health problems are diarrhea, dysentery, and the common flu. There is no phone in La Cumbre, and there is bus service to the city of Oaxaca once a week.

The primary activity in La Cumbre is agriculture, which is augmented by selling wood. Families tend to their own fields, which are sloped, deforested, and showing signs of erosion. Typical crops include corn, beans, and squash, which are primarily for family consumption rather than used as cash crops. In addition to family plots, the community is starting an experimental greenhouse. The most recent governmental development project was the installation of an electric corn mill, designed to alleviate women's work loads.

A group of fifteen women were interviewed in a communal meeting room. The ages ranged from 18 to 35 . Other people present included the social worker, a husband of one woman, and several young children. The interview lasted three 
hours.

The women were first asked to describe their typical daily work, and then their husbands' daily work schedule. They responded that they usually wake up between 5-6 a.m. and go to bed around 8 p.m. They said that grinding corn for tortillas takes the most time, although the village has an electric corn mill. The women are responsible for cooking, cleaning, working in the fields, collecting wood, caring for the children, and tending to elderly relatives. One woman added that they "have much more work than the men" who begin working at 8 or 9 a.m. and are typically responsible for working in the fields and collecting wood. The man present added that "women and men do the same work." This elicited much laughter from the women. He was countered by one woman who explained that women do the same work as the men, but the men do not help with women's work. The man responded, "We can't, we are tired." There was more laughter at this point.

Responding to questions regarding the tasks of collecting water and wood, the women answered that both women and men collect wood, and collecting water is not a problem because they have piped water. Finding wood, they continued, is more difficult now because most of the trees have been cut down by their village and others hoping to sell wood as fuel to communities whose resources have been depleted. At this point the women lamented that the forests are becoming so bare and that is now very difficult to find enough wood.

When questioned about the changes in work loads over the last five years, the 


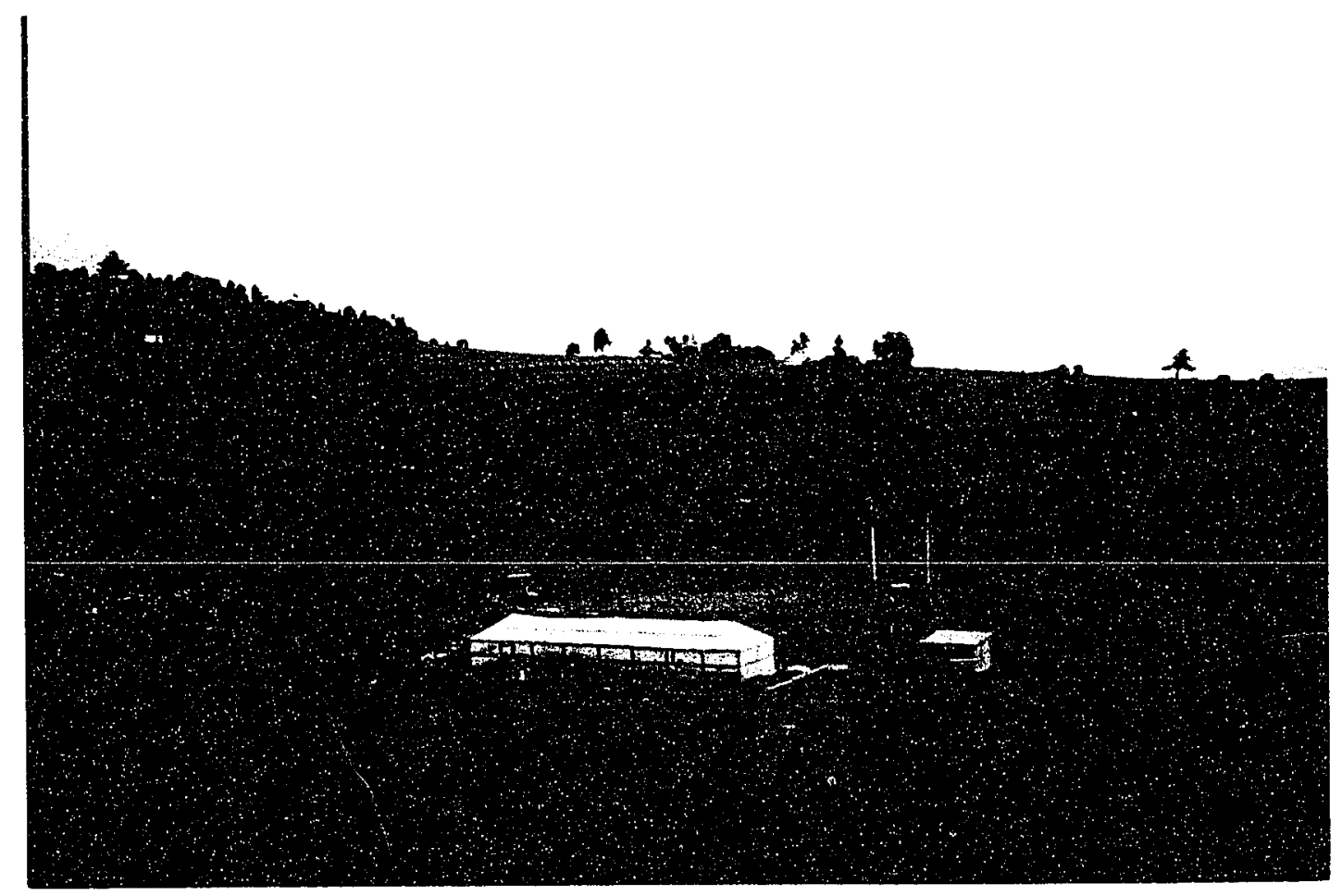

Figure 8. Communal farming area in La Cumbre marked by erosion. 


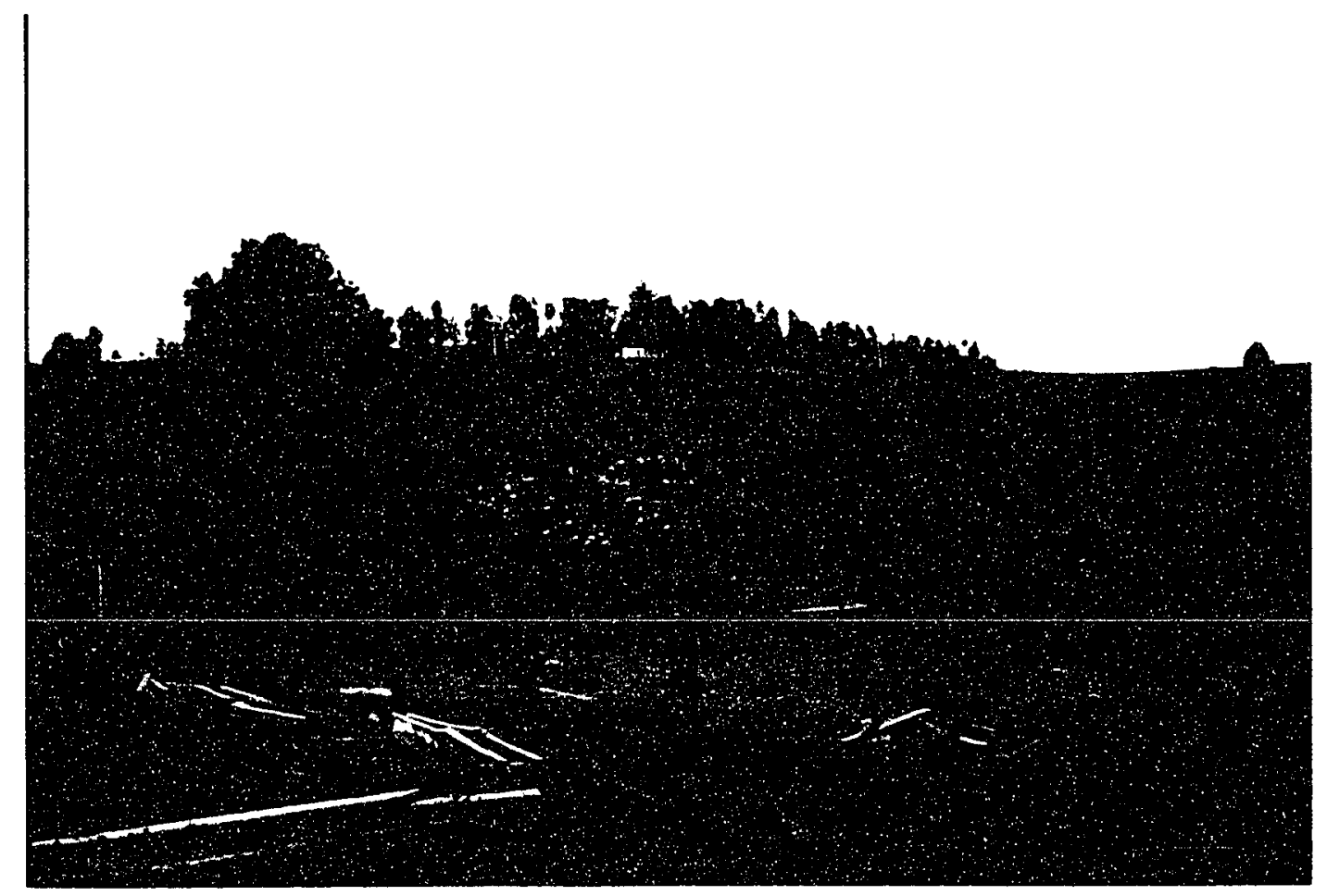

Figure 9. Erosion in La Cumbre farming area. 
women answered by saying that their work load has remained constant. They explained this by saying that although they must search longer for wood, they now have social services, electricity, and piped water, which makes other tasks easier. They said that the corn mill has helped, because now they wake up at 5 a.m. to make tortillas, where before they woke up at 2 a.m. One woman explained that she has lived in La Cumbre for many years, and now that they have electricity and piped water, they are able to sleep a little more and work a little less.

The women responded to questions regarding whether or not they were in financial need by stating that the economic conditions are decent because they are thus far sustainable in providing food, and obtain supplemental income by selling wood. They said it is more difficult to make an income now, because wood is harder to find. When asked why they need an income to supplement their lifestyle, they responded that with electricity and water, they now have taxes to pay. The women were asked about migration patterns and answered that there is little migration out of La Cumbre. One woman joked, "Why would anyone leave here?"

When asked about changes in the levels of wood and water available, and whether or not those changes have effected their work, the women answered that it is now difficult to find wood because the surrounding forests have been cut down. They said that men and women work together in finding wood, and that everyone works harder now in finding remaining trees. They also added that the soil is poor, and that they are unable to grow fruit. They reported that they can only get one harvest a 
year, where 10 years ago they could get several. They repeated that the land is bad, and that it used to be a lush forest. There was a lull in the conversation at this point as the women seemed to be thinking about the difficulties associated with poor land and inadequate forests.

Lastly, the women were asked what types of development aid they most desired. All of the women answered that they wanted more health services. The results of this interview can be found in Table 3.

\section{$\underline{\text { San Mateo }}$}

The second village visited was San Mateo. This community is situated on a sloping hillside, surrounded by a coniferous forest. The population totals 498 , with 253 men and 245 women. Residents here are mestizos, like in La Cumbre. San Mateo is also somewhat difficult to reach by car, and is $75 \mathrm{~km}$ from the city of Oaxaca.

The village of San Mateo has existed for over 7 years, and erosion and deforestation are easy to detect. Like La Cumbre, San Mateo was once covered with trees, but now remains bare. The village overlooks part of the valley of Oaxaca, and from this viewpoint it is easy to see patterns of deforestation (Fig. 10) The community is supported by electricity, "piped water," schools, and a corn mill. The piped water arrives in San Mateo through a series of metal pipes that are lined up in a shallow ditch alongside the major road (see Fig. 11). Some of the water runoff that flows down the ditch is captured in the pipes and is then directed to San Mateo. The 
water is not purified or treated and does not reach most households. In effect, San Mateo does not have any type of running water.

San Mateo is scheduled to receive another corn mill from La Programa de Apoyo para la Desarrollo de la Mujer. There are no medical services or phones. The nearest water source is a stream located $1 \mathrm{~km}$ from the village. Diarrhea and dysentery are the major medical problems. Agriculture is the primary activity in this community, with family plots of corn, beans, and squash. They do not sell any of their crops and merely subsist off of their harvests. Many men migrate to the city of Oaxaca in order to find paid work to supplement their subsistence.

In this village, 12 women were questioned in a communal office. Their ages ranged from 24 to 32 . The social worker was the only other person present. The interview lasted three hours.

When asked to describe their daily schedule, the women responded that they have no set schedule, but usually wake up between 3 and 6 a.m. They said they wake up earlier during planting season (Spring), when they make tortillas before going out into the fields. They go to sleep between 8 and 10 p.m. Their responsibilities include cooking, cleaning, finding water, caring for children, working in the fields, and tending to sick and elderly relatives. They said that the women have heavier work loads than men, whose responsibilities include working in the fields and finding wood. 


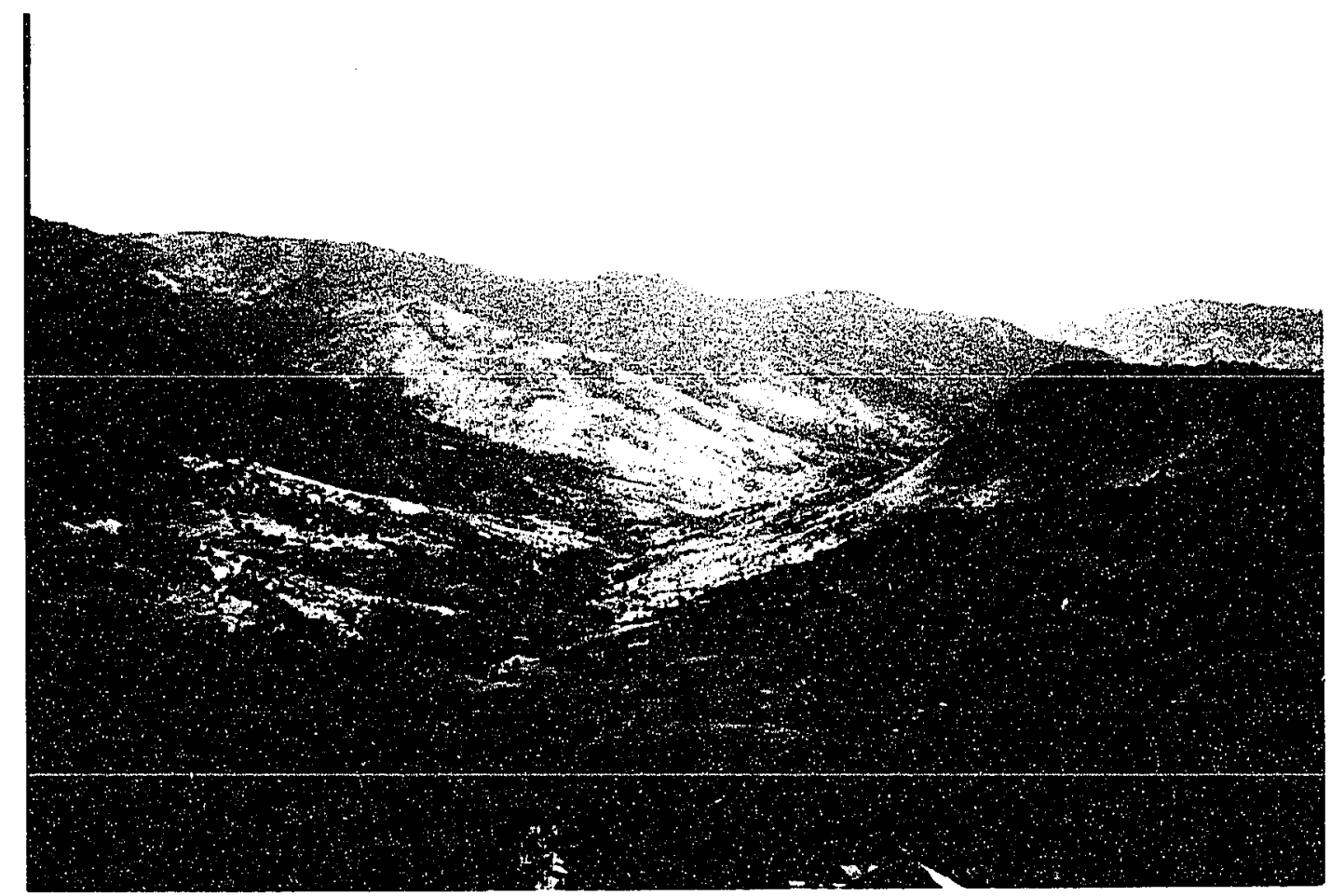

Figure 10. Deforestation in the hills surrounding San Mateo. 


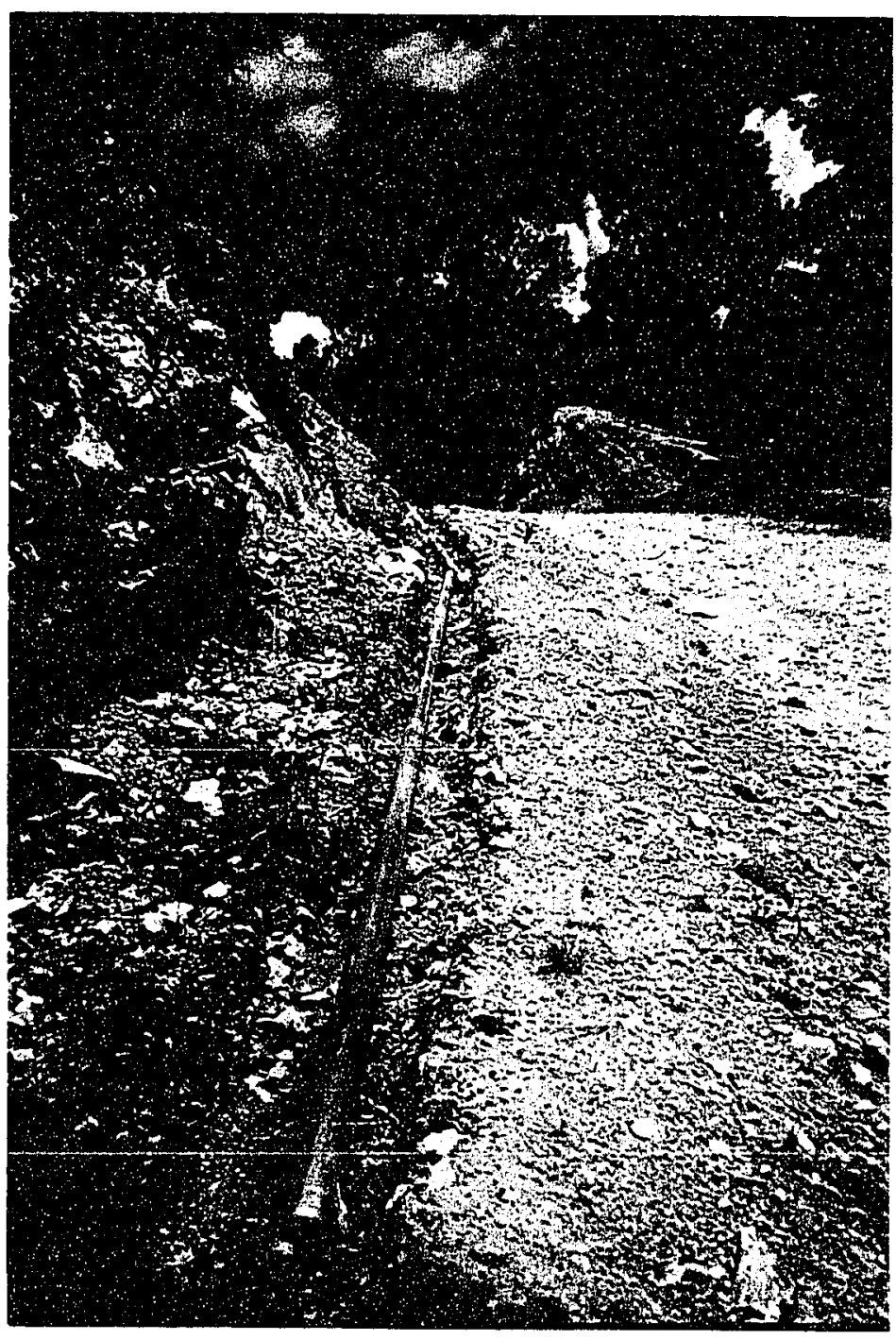

Figure 11. Pipe system providing water to San Mateo. 
The women responded to questions about collecting wood and water by saying that the men are responsible for collecting wood, but the women sometimes help. As it becomes harder to find wood, it is necessary for women to augment their chores by helping the men collect wood. Although San Mateo has electricity, every household does not. The women said that they can only cook with fuelwood, and because it is now scarce, it is difficult to cook. They believe that with more people out searching for wood, they are more likely to collect enough to meet their needs. The women said they were in charge of collecting water, which is difficult because the nearest source is over $1 \mathrm{~km}$ away. They said it is hard to carry sufficient amounts of water back to their houses. Although the community has piped water, the pipes rarely carry water. When the pipes were brought to the community, the women anticipated that the task of collecting water would be removed. One woman said, "We thought this [piped water] would make it easier for us, but it has done nothing." The women continue to spend several hours a day hauling water.

When asked if their work loads have changed over the last 5 years, the women said that their work has become increasingly difficult because wood is more scarce and water sources are drying up. They repeated that they have recently begun helping the men search for wood, which places more demands on their daily schedule. Due to the difficulties in water and fuelwood collection, the women reported that some days it is impossible to finish all their tasks. One woman added, "Some days we cannot do it" [finish their tasks]. In periods of drought, local streams dry up and 
water is difficult to find. They added that even in times of rain, collecting water can be difficult because drinking nearby stream water makes people ill. As a result, the women use other streams, usually further away.

The women responded to the question of their economic self-sufficiency by saying that in the past, they were completely self-sufficient in terms of food and clothing. Now, they said, they must find other work in order to provide these necessities for their families. Increased soil erosion has made it more difficult to grow food and women no longer have time to sew clothing. They said both men and women sometimes migrate to the city to work, but men are more likely to go because women are responsible for maintaining the family.

The women were asked about changes in the levels of wood and water surrounding San Mateo, to which they responded that deforestation and water scarcity are problems. They said that lately, the men have been leaving the village at $5 \mathrm{a.m}$. to search for wood so that the women can cook. Because piped water does not work and there is not much water in the nearby stream, water shortages have become a problem. They added that soil erosion is a problem, and that it has been difficult to maintain crops. When asked what types of social services they wanted most, the women answered that they need medical services and potable water.

\section{El Carrizal}

The last village visited was El Carrizal, a community perched along a steeply sloped hillside. Deforestation and erosion are severe (see Figs. 12 and 13). Large 
patches of deforestation are visible surrounding the village, especially on the other side of the valley. There is a narrow dirt road that cuts through the community and creates a flat plane through the village. Besides this road, most of the village is on a severe slant. Signs of erosion are common as deep fissures scar the mountains. Few trees remain near the village.

The community has been in existence only for the last five years. The total population is 350 , with 164 men and 196 women. The community is comprised mainly of Mixtecs, and residents speak both Mixtec and Spanish. El Carrizal is nearly impossible to reach by car, and is seventy kilometers from the city of Oaxaca. There is no bus service, and residents must walk several miles to the nearest road. There is no electricity, water, school, or medical service in El Carrizal. The nearest water supply is a stream one-half kilometer away, but residents say it is polluted. The major health problems are diarrhea, dysentery, and various stomach ailments, including parasites. El Carrizal has been promised a gas powered corn mill from La Programa de Apoyo para la Desarrollo de la Mujer.

Fifteen women were interviewed in El Carrizal, ranging from 17 to 33 years in age. The interview took place outside, while the women took a break from their work. The only other person present was the social worker. The interview lasted 2 $1 / 2$ hours.

The women described their typical daily schedules and said that they wake up 


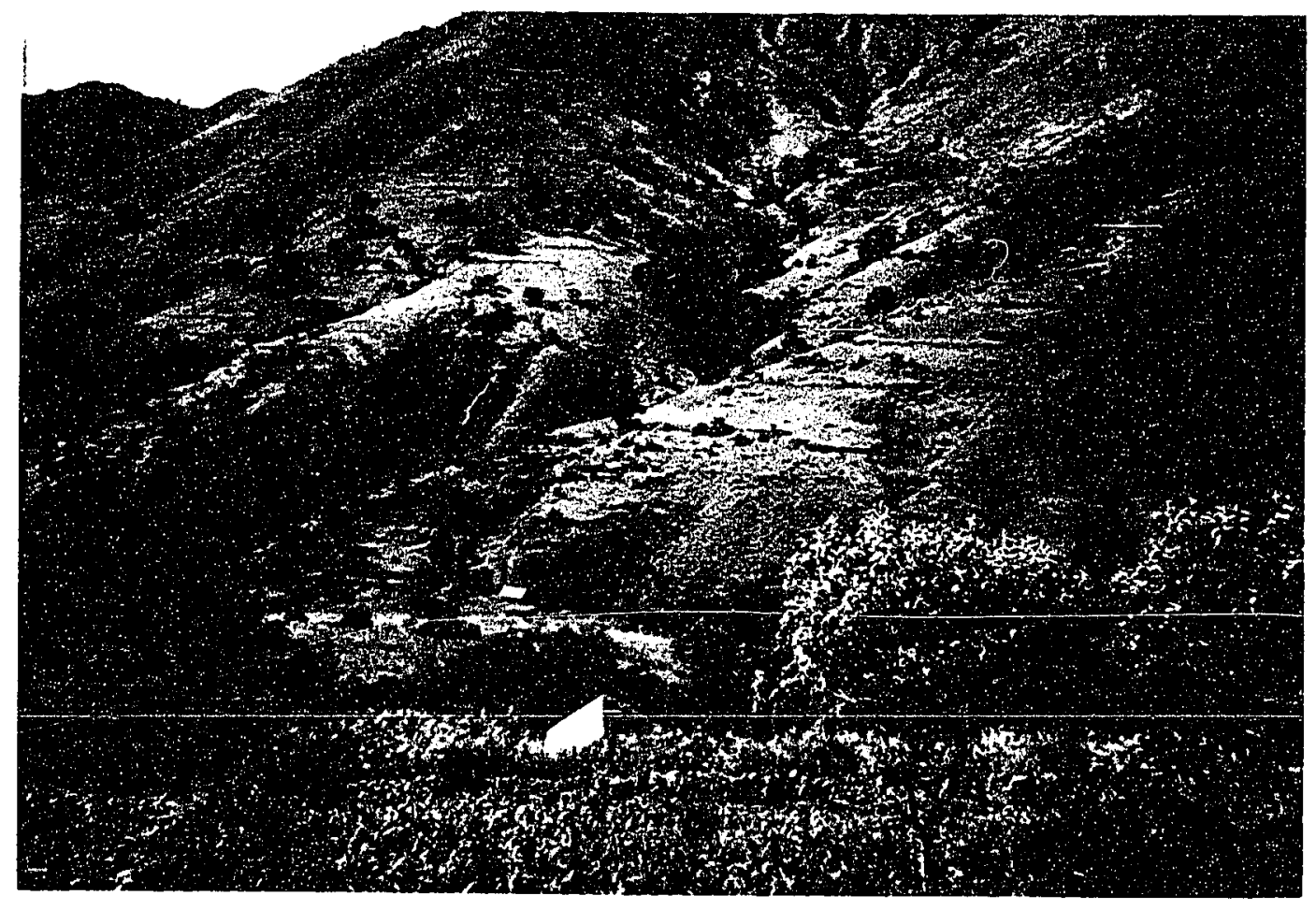

Figure 12. Deforested hills of El Carrizal. 


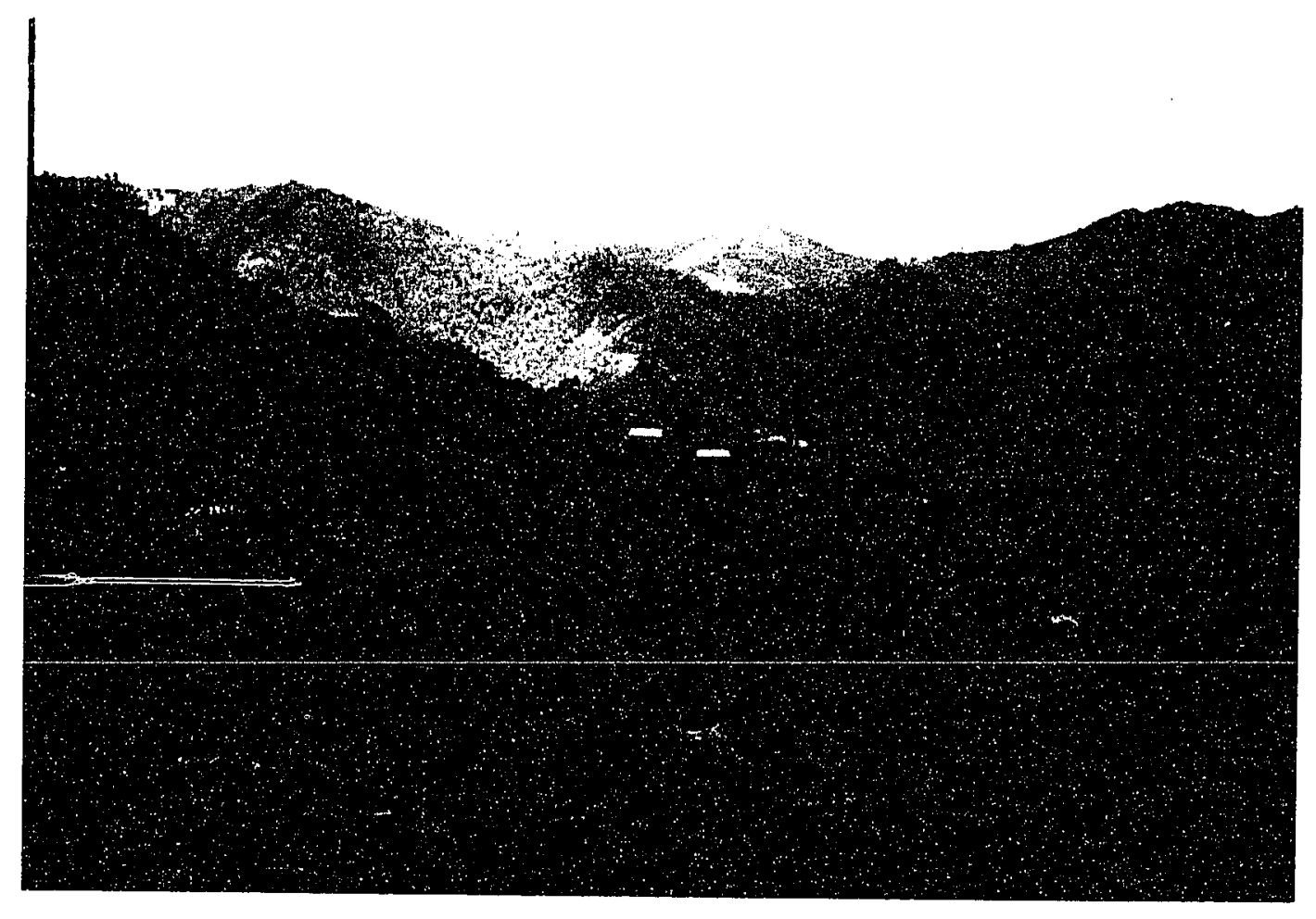

Figure 13. Deforestation in El Carrizal 
between 4 and 5 a.m., and spend most of their mornings grinding corn for tortillas. They said that they cook, clean, and then work in the fields before searching for wood. They said they then collect water, which is very difficult because there is none nearby. The nearest stream is polluted and makes people sick, and other water sources have dried up. They said they have to search much harder now for decent water, which takes up a lot of their time. The men are responsible for working in the fields and searching for wood. Men and women often spend many hours searching for wood together, yet sometimes they cannot find enough for cooking and heating.

Responding to questions about who collects water and wood, the women responded that they are solely responsible for collecting water, and that both men and women collect fuelwood. The women were then asked about changes in their work loads over the last several years and they responded that their workloads have become increasingly difficult, and that men too are working harder, but "not as much as the women." They explained this by saying that men spend most of their time in the fields. They look for wood too, but their primary responsibility is with the crops. Women on the other hand have many responsibilities, all equally important. One woman said, "We must take care of our families." When the growing season is over, men are more able to migrate to the city for work, because the women are the ones who take care of the children.

The women were then asked about their living conditions, and they answered that many people leave, both men and women, because there is not enough food. 
Many people migrate to the city of Oaxaca and other cities in Mexico and the United States. They said that the hope of finding jobs in order to provide food and shelter has led many residents to abandon rural life.

When asked about environmental conditions, the women said that it is difficult to find wood and water, and that erosion makes growing crops difficult. They said if the trees keep "disappearing" and there is no more water, they do not know how they can survive. They said they already spend most of their time working, and they cannot keep increasing their working hours. The women explained that deforestation is the result of too many people cutting down trees. They said there are more people in the area than in the past, and that there is not enough wood for everyone.

Lastly, when asked what social services they wanted the most, the women answered that they want medical services and a school.

\section{Analysis}

Several patterns emerged from the interviews relating to problems associated with deforestation and water scarcity. These patterns are self-evident but provide a basis to substantiate the larger issues. In addition to the issues of deforestation and water shortages, the themes of change, difficulties, and development can be seen throughout the interviews. The larger questions guiding this thesis (how women are affected by resource depletion and what are women doing to alleviate their burden) are examined as well. 
TABLE 3

DATA CHART ON THE THREE VILLAGES STUDIED

\begin{tabular}{||l||l|l|l||}
\hline & La Cumbre & San Mateo & El Carrizal \\
\hline \hline Distance from Oaxaca & $35 \mathrm{~km}$ & $75 \mathrm{~km}$ & $70 \mathrm{~km}$ \\
\hline Total population & 324 & 498 & 360 \\
\hline Total Male/Female & $151 / 173$ & $253 / 245$ & $164 / 196$ \\
\hline Ethnicity & Mestizo & Mestizo & Mixtec \\
\hline Primary activity & Agriculture & Agriculture & Agriculture \\
\hline Supplemental income & Selling wood & $\begin{array}{l}\text { None, but } \\
\text { migration } \\
\text { common }\end{array}$ & $\begin{array}{l}\text { None, but } \\
\text { migration } \\
\text { common }\end{array}$ \\
\hline Bus service & Yes & No & No \\
\hline Electricity & Yes & Yes & No \\
\hline Piped water & Yes & $\begin{array}{l}\text { Yes, but } \\
\text { inefficient }\end{array}$ & No \\
\hline Water shortage & No & Yes & Yes \\
\hline Signs of erosion & Yes & Yes & Yes \\
\hline Signs of deforestation & Yes & Yes & Yes \\
\hline Typical health problems & $\begin{array}{l}\text { Diarrhea, } \\
\text { dysentery, } \\
\text { flu }\end{array}$ & $\begin{array}{l}\text { Diarrhea, } \\
\text { diphtheria, } \\
\text { flu }\end{array}$ & $\begin{array}{l}\text { Diarrhea, flu, } \\
\text { parasites }\end{array}$ \\
\hline Yes & No & No \\
\hline Access to health service & Yes & Yes & No \\
\hline Corn mill & &
\end{tabular}


Answers to questions. Relating to the linear questions posed at the beginning of this chapter, various answers have been obtained. Table 4 outlines the results.

TABLE 4

ANSWERS TO QUESTIONS

\begin{tabular}{||l|l|l|l||}
\hline & La Cumbre & San Mateo & El Carrizal \\
\hline $\begin{array}{l}\text { Is fuelwood } \\
\text { increasing or } \\
\text { decreasing? }\end{array}$ & Decreasing & Decreasing & Decreasing \\
\hline $\begin{array}{l}\text { What is the } \\
\text { evidence for the } \\
\text { increase? }\end{array}$ & $\begin{array}{l}\text { Personal } \\
\text { observations; } \\
\text { women's } \\
\text { testimony; } \\
\text { archival data }\end{array}$ & $\begin{array}{l}\text { Personal } \\
\text { observations; } \\
\text { women's } \\
\text { testimony; } \\
\text { archival data }\end{array}$ & $\begin{array}{l}\text { Personal } \\
\text { observations; } \\
\text { women's } \\
\text { testimony; } \\
\text { archival data }\end{array}$ \\
\hline $\begin{array}{l}\text { Are women } \\
\text { spending more } \\
\text { time collecting } \\
\text { wood? }\end{array}$ & Yes & Yes & Yes \\
\hline $\begin{array}{l}\text { Is water increasing } \\
\text { or decreasing? }\end{array}$ & $\begin{array}{l}\text { Water supply is } \\
\text { static }\end{array}$ & Decreasing & Decreasing \\
\hline $\begin{array}{l}\text { What is the } \\
\text { evidence for the } \\
\text { decrease? }\end{array}$ & $\begin{array}{l}\text { N/A because } \\
\text { water supply is } \\
\text { static }\end{array}$ & $\begin{array}{l}\text { Women's } \\
\text { testimony; } \\
\text { archival data }\end{array}$ & $\begin{array}{l}\text { Women's } \\
\text { testimony; } \\
\text { archival data }\end{array}$ \\
\hline $\begin{array}{l}\text { Are women } \\
\text { spending more } \\
\text { time collecting } \\
\text { water? }\end{array}$ & No & Yes & Yes \\
\hline $\begin{array}{l}\text { Do the women } \\
\text { perceive their } \\
\text { burdens as being } \\
\text { heavier than in the } \\
\text { past? }\end{array}$ & No & Yes & Yes \\
\hline
\end{tabular}




\begin{tabular}{||l|l|l|l||}
\hline $\begin{array}{l}\text { Have any } \\
\text { development } \\
\text { projects occurred } \\
\text { in response to } \\
\text { hardships faced by } \\
\text { residents? }\end{array}$ & $\begin{array}{l}\text { Yes, a corn } \\
\text { mill, electricity, } \\
\text { and running } \\
\text { water }\end{array}$ & $\begin{array}{l}\text { Yes, a corn mill, } \\
\text { electricity, and } \\
\text { running water }\end{array}$ & $\begin{array}{l}\text { No, but a corn } \\
\text { mill is underway }\end{array}$ \\
\hline $\begin{array}{l}\text { Are these projects } \\
\text { perceived as } \\
\text { successful } \\
\text { responses? }\end{array}$ & $\begin{array}{l}\text { Yes, to a } \\
\text { certain degree. } \\
\text { The women } \\
\text { maintain that } \\
\text { these services } \\
\text { have freed up } \\
\text { some of their } \\
\text { time, but } \\
\text { environmental } \\
\text { factors have } \\
\text { caused them to } \\
\text { spend more } \\
\text { time on other } \\
\text { chores. }\end{array}$ & $\begin{array}{l}\text { No, because } \\
\text { these services are } \\
\text { inefficient and } \\
\text { have not affected } \\
\text { most households. } \\
\text { Environmental } \\
\text { factors are } \\
\text { responsible for } \\
\text { increasing work } \\
\text { loads, and } \\
\text { nothing has been } \\
\text { done to address } \\
\text { those problems }\end{array}$ & N/A \\
\hline
\end{tabular}

The final question (not posted on this chart) examines whether there is a difference in patterns among villages. The following paragraphs outline the various patterns evident in the interviews, and give shape to the meaning of the data.

Deforestation. All of the women interviewed reported that deforestation has increased, and this in turn has expanded work loads for both women and men. In La Cumbre and El Carrizal, women traditionally search for wood alongside men, while in San Mateo, women have only recently begun collecting wood in order to extend the 
likelihood of finding fuelwood. In La Cumbre, finding wood is an economic necessity, but is not crucial to basic survival because they use electricity for cooking. The lack of available wood however, threatens their economic base, which in turn threatens their livelihood; if residents are unable to pay taxes and other utility fees, they may lose electrical and water services, which will impede on their lifestyle. Because there already exists a shortage of wood, requiring fuelwood for cooking would be difficult in La Cumbre. The women in La Cumbre reported that although they have amenities, such as piped water and electricity, their overall workload has remained constant because deforestation has caused them to spend more time searching for wood.

In San Mateo. where electrical and water services are new, women's workloads have increased because of deforestation. Inefficient services have failed to reach most residents, so consequently residents live as they did without these amenities. Regarding deforestation specifically, women in San Mateo have incorporated the traditionally male task of collecting wood into their schedules in order to ensure adequate finding of fuelwood. Women are unable to cook, one of their primary tasks, without fuelwood, and have thus become obligated to help find sufficient material. Without fuelwood, basic survival is threatened in San Mateo.

In El Carrizal, basic survival is also threatened by deforestation. As in San Mateo, residents are dependent upon fuelwood for cooking. Both women and men in El Carrizal collect wood, but lack of resources makes this task difficult. The women 
in El Carrizal complained about increasing workloads and reported that they (all residents) may not be able to survive as deforestation continues and impedes upon women's abilities to cook for their families.

Water scarcity. Water scarcity is only a problem in San Mateo and El Carrizal, where residents are dependent upon fresh water sources; in La Cumbre, piped water supplies the entire village. In both San Mateo and El Carrizal, women are the water collectors, and do so without help from the men. Women in San Mateo reported that water scarcity impedes their ability to collect enough water, especially in periods of drought. Exacerbating the problem is the distance from the nearest water source: Women in San Mateo stated that because their most reliable water source is at least one kilometer away, it is difficult to carry all the water they need. This requires the women to make several trips.

In El Carrizal, both water scarcity and water pollution are problems. The women reported that several nearby water sources have dried up, possibly from overuse, and others "make people sick." This has led the women to search several hours longer for other water sources, along with searching harder for wood, and has made their workloads almost unbearable. In San Mateo and El Carrizal, where residents are directly dependent upon the natural environment for survival, deforestation and water scarcity first effect those responsible for their collection, mainly women, and inhibit women's abilities to complete their familial maintenance tasks. Because these tasks, such as preparing food and providing water, are 
inextricably linked to community survival, wood and water depletion threaten rural life in San Mateo and El Carrizal.

Change. The theme of change is prevalent throughout the interviews, especially relating to changes in the natural environment. In all the villages, the supply of wood has changed with increasing deforestation. All of the women reported that this change in wood supply has led them to work harder. Even in La Cumbre, where development has brought electricity and piped water, women report no difference in work loads due to a change in levels of wood available. In San Mateo, deforestation has led to a change in women's tasks: When trees were more abundant, collecting wood was exclusively a male task; now with a fuelwood shortage, women have adopted the chore of collecting wood too. In San Mateo, this change has led women to question their ability to complete their tasks, and has added enormous pressures. In El Carrizal, changes in tree levels cause both men and women to search longer for wood.

Change is also evident in water availability. In both San Mateo and El Carrizal, a change in water supply has led to an increase of work loads. As women work harder in order to supply their families with water, they are unable to finish other tasks. Eventually the women must compromise and either search less for water and bring home a smaller amount, or continue searching for adequate water and decrease the time spent on another chore, such as finding fuelwood or working in the fields. These communities are prevented from living a subsistence lifestyle because 
changes in resource levels impede their ability to gather enough natural materials to sustain themselves.

Difficulty in completing tasks. The theme of difficulty arises in conjunction to the theme of change: As resource levels change (decrease), both work and daily survival become more difficult. In La Cumbre, women reported that finding wood is more difficult because of increasing deforestation. This, they said, makes it more difficult to make an income, because they sell the wood to other communities.

In San Mateo, deforestation has forced women to participate in gathering wood, making their work loads more difficult. Furthermore, collecting water is demanding because nearby water sources are drying up or are becoming polluted. This forces women to look harder for water. The women in San Mateo summed up their feelings of hardship by stating that due to the difficulties in water and fuelwood collection, some days they are unable to complete all of their tasks. In a society where all tasks relate to daily survival, incompletion can have serious repercussions.

In El Carrizal, women also report difficulty due to changes in resource levels. The women said water collection is hard, because there is little drinkable water nearby. Wood collection is difficult because there are few trees remaining in the surrounding area. The women in El Carrizal stated that they already spend most of their time on survival tasks, and cannot endure increased workloads. Because rural life is becoming so difficult, many residents migrate to urban areas. Development. Development is often seen as a cure for rural hardships, but in the 
villages where development has occurred, residents are still faced with difficulties. In La Cumbre, development has brought them electricity, running water, and a corn mill. Women's work loads have not decreased however, because they are still dependent upon collecting wood, which has become more scarce. Development has also signified higher taxes, which places additional pressures on the villagers (and local resources). In San Mateo, running water is inefficient and does not reach most households. Women are therefore still responsible for collecting water. Electricity has not seemed to have improved their condition either. Like in La Cumbre, the dependence on natural resources supersedes any technological improvements, if those improvements do not address the issues of resource scarcity.

Looking at the Larger Issues

The larger issues concerning this study are broken down into two questions: How are women's lives affected by resource scarcity and how do women respond to the ensuing resource shortage? In answering the first question, the interviews show that the women in La Cumbre, San Mateo, and El Carrizal have all been affected by a shortage in either water or fuelwood or both. The women are faced with heavier burdens due to the shortages because, as primary caretakers of the family, they are responsible for providing these necessities. The theme of change, evident in all of the interviews, shows that a change (decrease) in water and wood is correlated with a change (increase) in work loads. This inverse relationship is true in all of the villages. It is then postulated that as water and wood become increasingly scarce, the 
women's workloads will become more difficult until they will no longer be able to support their families. In El Carrizal, the women unanimously declared that resource scarcity has made their workloads almost unbearable. In El Carrizal and San Mateo, survival depends on the collection of wood and water; without these resources, rural life is threatened.

In answering how women respond to the resource shortage, it is crucial to note that all of the women reported to working longer hours, although most already work ten hours each day. As the women work more to find more water and wood, they are themselves becoming agents of resource destruction. For example, the women from La Cumbre reported that the surrounding forest is so bare that it is difficult to find wood. As they search harder to find much needed wood, they perpetuate ecological damage and contribute to deforestation. The same is true for the women in San Mateo and El Carrizal.

Another way in which women are responding to the shortage of wood and water is by adopting new tasks, especially in San Mateo where fuelwood collection is new to women. The shortage of necessary wood has caused a breakdown in traditional gender assignments associated with this task, but its adoption follows a logical rationale: Because a shortage of fuelwood threatens women's abilities to cook, an inability to collect enough wood threatens familial maintenance; and because women are responsible for maintaining the family, gathering wood now becomes one of their tasks. 
Conclusion

As women's work becomes more difficult and as they cross gender lines in order to assume more responsibilities, it is doubtful that women can continue this trend of increasing hardship. Women are the foundation of rural life, providing for the entire family, and if they are unable to complete their responsibilities rural survival is threatened. Interviewing and observing the women in the three villages has made these assumptions clearer and has given insight into the realities of their dependence on the natural environment.

Deforestation and water scarcity are serious threats to the delicate ecosystems in Oaxaca, and also pose a threat to a traditional way of life. The rural peasants depend upon a healthy environment to sustain them, and in turn, the environment can only remain healthy if properly managed. In answering the research questions posed, the following observation has surfaced: For the families in La Cumbre, San Mateo, and El Carrizal, their natural environment is already declining, and thus they scramble to extract the remaining resources for their own survival. This desperate cycle can only worsen the situation for both the rural peasants and the natural environment.

The process by which this thesis researched the proposed questions has uncovered more issues that need further study, namely: What immediate solutions can rejuvenate the natural environment while relieving the burden of rural women; and what can be done to alleviate the long-term ramifications of uneven development? 
The feminist perspective that guided this study has indeed been crucial in answering the research questions while giving latitude to explore other avenues of concern. This thesis may now be used as a foundation for understanding the true relationship between water and fuelwood scarcity and rural Oaxacan women's lives, and as a source of identifying further questions and concerns that need immediate attention in order to halt the destructive cycle that plagues rural peasants. 


\section{CHAPTER 5}

\section{OAXACAN WOMEN AND ENVIRONMENTAL DETERIORATION: SOME CONCLUDING THOUGHTS}

This thesis provided three case studies that documented how women are becoming victims of environmental impoverishment and how their subsequent use of scarce resources further degenerates the environment. In addressing these issues three questions were asked: How are women's lives affected by resource scarcity, how do women respond to the ensuing shortage, and what are the implications of the answers? A feminist perspective that focuses on a holistic understanding was used in formulating the research questions, directing the scope of the study, and analyzing the data. This perspective allowed the study to focus on the subjective experience of the women, which was crucial in answering the research questions, instead of concentrating on the rates of environmental change and other scientifically measurable variables.

In assessing the affects of resource scarcity on rural Oaxacan women's lives and how the women have responded to the resource shortage, it is clear that women are operating under a system of crisis management. Not only is their daily work becoming more difficult, but their level of survival is also becoming more difficult to maintain. Because women are charged with finding fundamental resources, they are 
increasingly unable to fulfill their duties. This in turn affects the entire family. Their crisis stems from two overriding issues: A cycle of environmental destruction in which women perpetuate resource depletion by merely using water and trees for their personal needs, and a larger governmental system that promotes uneven development and ensures the marginalization of rural peasants.

The latter issue, uneven development, arises from a history of governmental support of economic expansion at the expense of rampant poverty among rural peasants. As a direct consequence of agribusiness and industrial expansion, peasants have been forced off their own lands onto more marginal lands. By farming these marginal areas, the peasants are thrust into the cycle of environmental depletion and rural poverty.

\section{Answering the Research Questions}

The interviews and observations in this thesis explained how rural Oaxacan women's lives are affected by water and wood shortages and how they are compensating for these changes. From the data we observed that in La Cumbre, San Mateo, and El Carrizal the women's burdens are becoming heavier. In La Cumbre, the village is supplied with running water and electricity so they do not collect water and the collection of wood functions as a source of income. The villagers need this income in order to support the services of electricity and running water. This brings up questions regarding the appropriateness of development initiatives: If modern services are designed to free peasants from chores such as collecting wood and water, 
yet the cost of these services force the peasants to continue gathering wood, what real progress has been made? This question stirs up a common wariness about the ramifications of development projects. In San Mateo, where electricity and running water are supposed to help villagers but are inefficient and do not reach the people, the women reported to working longer hours. In these cases, development has done little to aid local families. As is the case with much Third World development, these initiatives are ineffectual due to their inappropriateness or inefficiency. La Cumbre and San Mateo afford us a glimpse into the different ways in which development is inadequate and show how the people, particularly women, are coping.

In the villages of San Mateo and El Carrizal, where the peasants are dependent upon the collection of wood and water, women's workloads have become heavier, and as a consequence their abilities to provide the basic necessities for their families is threatened. In both villages women reported to working long hours and were distraught over their inability to complete survival tasks. In San Mateo, the women reported spending more time collecting water while adding the chore of gathering wood. In El Carrizal, one woman stated that she doesn't know how she will cope in the future if her work continues to become more difficult. With schedules that are already full, the women are unable to complete all of the tasks and they find themselves in the midst of a crisis.

An important implication of the research findings is that women unwittingly worsen their own situation. As the environment becomes more depleted and as the 
Oaxacan women work harder to find water and wood, they too are robbing the land of precious resources. The areas surrounding the villages are already stripped of wood and dry from drought, yet the needs of rural families remain the same. Their level of need is not correlated with the level of resources, so in their fight for survival the women search for new sources of wood and water. At one time the land could support them, but now with increased pressure from other sources, there are too many demands on the environment. Whatever these demands may be (overpopulation, industrial use of resources, etc.), they force rural families into a cycle of depletion in which rural women are becoming destructive forces in an effort to maintain their families. This cycle challenges the survival of the environment, the rural villagers, and an age-old way of life.

These issues need further study in order to understand the state of the natural environment and the problems faced by poor, rural peoples in Oaxaca. Furthermore, Mexico's push for increased development suggests that development may soon be prevalent in Oaxaca. Extraction of natural resources, agribusiness ventures, and irrigation projects may be initiated in Oaxaca, and without information on the current ecological and ethnographic states, this form of uneven development could be disastrous. While the government may prosper from economic gains, it will not compensate the hundreds of thousands of poor rural people, displaced from their lands and without food or shelter. Furthermore, the creation of a displaced population is already occurring, as indicated by the villages studied. With more information on 
these rural areas, the government would be able to intervene and stop the crisis that is already occurring. Truly effective aid programs can only be initiated with in depth knowledge about the relationship between rural people and the environment.

\section{Global Implications}

The results of this thesis stretch beyond the three small villages in Oaxaca and apply to broader areas. First, the model of feminist environmentalism explains that the relationship between women and the environment needs to be better understood and that a holistic context must be assigned to environmental degradation. By integrating the philosophies of feminist environmentalism it is easy to understand how women are victims of resource scarcity and why they must be part of the solution. The three case studies in this thesis are both guided by this model and present evidence that supports its claims. This thesis does not a represent a singular phenomena, but rather is incorporated into the scope of a larger model.

In accordance with the feminist environmentalism model, this thesis supports the feminist perspective and demonstrates how it is possible to obtain valuable information using non-conventional methods. This perspective has allowed a subjective analysis of the data and has encouraged the development of new questions throughout the research process. Had this study employed strict scientific methods, it would have been much more difficult to understand the perceptions and attitudes of the women.

The information obtained through this thesis contributes to a growing pool of 
information on Oaxaca, Mexico, and Latin America in general. Because the problems concerning rural peoples and environmental degradation are relatively unknown in Latin America, every case study is important in bridging the information gap. As more information is compiled, the government and private agencies can begin accurately addressing the rampant environmental degradation.

Lastly, the villages of La Cumbre, San Mateo, and El Carrizal represent more than three small villages in Oaxaca; they represent a microcosm of rural life and symbolize the fragile web of life. While it is important to remember that the structure of rural families and communities differ greatly and cannot be generalized, a growing amount of research suggests that many rural women worldwide are experiencing increased burden due to a deteriorating natural environment. This implies that the connection between women and the environment is a global issue, manifested in worldwide environmental degradation. Upon closer inspection, it may become apparent that the causes of environmental decay and women's responses to it are similar, despite cultural and geographic differences.

\section{Suggestions for Future Research}

This thesis addressed only a small portion of the larger issues concerning rural Mexican women in Oaxaca, and attempts to fill in the gaps in one specific area. This study concentrated on the consequences of environmental degradation, but did not focus on the causes or solutions of those environmental problems nor on their effects on women. These questions should be addressed in a separate study. The larger 
issues framing future research are: What short-term remedies can rejuvenate the natural environment while alleviating women's burdens, and what long-term solutions can ease the effects of uneven development? These issues are too large to answer in one study, so they must be broken down into manageable topics.

The following represents basic guidelines which organize the remaining research needs, and put this thesis in a larger perspective (see Table 5). First, the question of "why" needs to be answered: Why is environmental destruction taking place in Oaxaca? Archival research (included in this thesis) gives some background information, but more in-depth study needs to be done in order to ascertain who specifically is responsible for this destruction.

Secondly, the question, "what are the consequences of environmental degradation" should be addressed. This thesis fits into this category, as it answers what the consequences are on rural women. Other issues that need to be studied include, what are the ecological consequences, the economic consequences, and potential urban consequences.

Thirdly, "how can these effects be mitigated?" This should be better understood. Research needs to be conducted to determine what types of projects could slow the rate of ecological decay and what can be done to help the people adapt to the barren environment.

Lastly, various development programs and environmental groups should be studied in order to discover whether someone is already working on a solution, either 
in Gaxaca or elsewhere in Mexico. Perhaps this type of research will uncover a successful model to emulate.

TABLE 5

SUGGESTIONS FOR FUTURE RESEARCH

\begin{tabular}{||l|l||}
\hline Question & Components \\
\hline $\begin{array}{l}\text { Why is environmental destruction } \\
\text { taking place in Oaxaca? }\end{array}$ & $\begin{array}{l}\text { How are individuals contributing? } \\
\text { How is industrialization contributing? } \\
\text { How is uneven development } \\
\text { contributing? } \\
\text { What are some other reasons? }\end{array}$ \\
\hline $\begin{array}{l}\text { What are the consequences of } \\
\text { environmental degradation? }\end{array}$ & $\begin{array}{l}\text { What are the ecological consequences? } \\
\text { What are the economic consequences, } \\
\text { both rural and urban? } \\
\text { What are the urban consequences? }\end{array}$ \\
\hline $\begin{array}{l}\text { How can the environmental degradation } \\
\text { be better understood and therefore } \\
\text { mitigated? }\end{array}$ & $\begin{array}{l}\text { What gaps are there in knowledge } \\
\text { about the environmental situation? } \\
\text { What issues need further study? }\end{array}$ \\
\hline $\begin{array}{l}\text { Which environmental groups and } \\
\text { governmental agencies are already } \\
\text { addressing problems associated with } \\
\text { environmental degradation? }\end{array}$ & \\
\hline
\end{tabular}

\section{$\underline{\text { Recommendations }}$}

This thesis addressed an important aspect of environmental destruction in

Oaxaca, Mexico, one that needs immediate attention and further research. Women 
are struggling to maintain their families, amidst an environment of scarcity, and are realizing the limitations of the parched earth. These women are offered few choices, and must decide between retaining their rural lifestyle, causing further damage to the land while living in resource-poverty, or immigrating to the already crowded cities and living in economic poverty. Sustainability is neither an option nor a reality, it is merely a fabled reminder of life in the rural past. As more rural peasants decide to leave their land and venture to urban centers, a way of life is disappearing.

These same problems plague much of the developing world, yet some areas have begun to aggressively address the consequences of environmental degradation and new models of development are emerging. Mexico should examine successful projects and discover how rural Mexican women can be incorporated into environmental development initiatives. Because Mexican women are so inextricably responsible for familial maintenance, they must be offered support in preserving their lifestyles. Furthermore, in order to curb environmental deterioration, rural families must be given alternatives in gathering resources from the already resource-poor land. By including local people into the development project, both rural families and developers can learn about the natural environment, and rural people can obtain a sense of hope and pride in their surrounding environment. In order to end the cycle of destruction in which rural families and the rural ecology are threatened, Mexico must convert to a cycle of regeneration where people actively work in rejuvenating the land. Such policies will increase general well-being, improve the environment, 
and sustain development. Furthermore, the policy of uneven development needs to be addressed and alternatives must be offered.

Women hold the key to regeneration because they are responsible for gathering natural resources. This means that women are privy to knowledge about the environmental conditions of their villages. Therefore, women should be consulted about the ecological problems in their areas and incorporated into the solution process. Because women are most concerned with tending to their families, they would greatly benefit from a heathy environment; therefore, their goals are the same as environmentalists. With women's knowledge and cooperation, Mexico can begin healing its ailing environment, and begin a program of collaboration and change. Women have proven in other areas that they can be positive agents of change. Instead of remaining victims of a patriarchal system, women worldwide are rising above common constraints and emerging as leaders in the environmental movement. The government of Mexico should offer its rural women a chance to use their abilities in improving the environment and forge and alliance in creating a viable solution. The rural women in Oaxaca, and perhaps elsewhere in Mexico, can not only be natural resource consumers, but natural resource healers as well.

Perhaps the most important aspect of this study is the guidance of a feminist perspective. This thesis is a synthesis of many disciplines and falls under the realm of environmental studies because it examines the human-environment interaction. Evidence of deforestation and water scarcity in Oaxaca has been offered through 
secondary sources so that this study may focus on the attitudes and beliefs of rural women. Because we know that environmental depletion is occurring, for the purposes of this study it is not necessary to study mathematical rates or statistical relations.

Environmental studies often embraces traditional scientific methods, yet this study required a subjective understanding that cannot be measured by objective means. Objectifying the methods and analysis would only serve to remove the issues from their context; for rural peasants ecological impoverishment signifies a threat to survival rather than a matrix of quantifiable data. It is important to employ scientific methods when studying quantifiable questions, but when addressing involved humanenvironment relationships a holistic subjective philosophy should guide the study.

Environmental studies should embrace a feminist perspective when studying complex human relationships. For the peasants in Oaxaca, their crisis warrants immediate attention and insightful analysis if a meaningful solution is to be formulated. Environmental studies needs to understand the implications of a feminist perspective in academia, research endeavors, and especially in projects concerning women if we hope to address problems involving people and the environment. This thesis offered support for this position by demonstrating the feasibility of coupling a feminist perspective with a meaningful analysis.

Conclusion

What does this mean for environmental policy? How can this thesis contribute to policies of social change and environmental restoration? We can use this thesis and 
the women's stories to understand the crises they face and the unique relationship they share with the environment. Environmental policy change can come about by incorporating the philosophies of the feminist perspective and feminist environmentalism into the planning process. By acknowledging that women are both victims of environmental change and sources of knowledge about natural resources, we can begin to view women as agents of environmental restoration. Furthermore, by recording women's experiences we can build an understanding of the complex human-environment connection in rural societies.

This thesis offers a case study that documents women's experiences in Oaxaca, Mexico. The women in La Cumbre, San Mateo, and El Carrizal suffer from stress due to a shortage of wood and water, yet their problems run much deeper than resource scarcity. Because their lives are cemented into a gendered differentiation of labor and because they live within a system that fosters environmental destruction, women are trapped by the powerful forces surrounding them. The women in the villages continue to provide food, water, and fuelwood for their families, yet their access to resources is declining. Uneven development has forced peasants onto marginal land and has sown the seeds for a cycle that aggravates environmental decay. This trend worsens as women scour the resource-poor environment in order to find the few remaining resources, which they then extract, and cause further ecological deterioration. The women continue to scrape the land until the land becomes sterile, or the women are exhausted and unable to endure their heavy burden 
or both, which then threatens a traditional way of life. Women's ecological knowledge and their needs are ignored by governmental planners and developers.

If Mexico hopes to save its fragile environment, it must concentrate on restoration. In order to achieve true success, planners must not only incorporate women into the solutions; but they must also understand women's place in rural societies and how gender functions as a social construct. Planners must also accept women's contribution to sustainability and consult women regarding the feasibility of restorative processes. Once planners reorient their top-down methods of development and incorporate women and gender-specific issues into solutions, then Mexico can begin to save its delicate environment and forge a relationship between women and environmental sustainability. 


\section{REFERENCES}

Acosta-Belin, Edna and Christine E. Bose. 1990. From structural subordination to empowerment. Gender and Society 4(3): 299-320.

Acevedo, Maria Luisa, and Ivan Restrepo. 1991. Los valles centrales de Oaxaca. Oaxaca: Centro de Ecodesarrollo.

Agarwal, Bina. 1992. The gender and environment debate: Lessons from India. Feminist Studies 18(1): 119-159.

Alvarez, Luis Rodrigo. 1983. Geografia del estado de Oaxaca. Oaxaca: Gobierno de Oaxaca.

Arizpe, Lourdes and Carlota Botey. 1987. Mexican agricultural development policy and its impact on rural women. In Rural women and state policy, ed. Carmen Deere and Magdalena Leon. Boulder: Westview Press.

Arriagada, Irma and Johanna Noordam. 1982. Las mujeres rurales Latinoamericanas y la division del trabajo. In Las trabajadoras del agro, ed. Magdalena Leon. Bogota: ACEP.

Barkin, David and Billie R. DeWalt. 1988. Sorghum and the Mexican food crisis. Latin American Research Review 23: 3.

Beneria, Lourdes. 1982. Women and development. The sexual division of labor in rural societies. New York, NY: Praeger Publishers.

Bernard, F. Russell. 1988. Research methods in cultural anthropology. Newbury Park: Sage Publications, Inc.

Bezaury, Josefina Aranda. 1988. Las mujeres en el campo. Oaxaca: Universidad Autonoma Benito Juarez de Oaxaca.

Buvinic, Mayra, Lycette, Margaret, and McGreevey, W.P. 1983. Women and poverty in the third world. Baltimore, MD: The Johns Hopkins University Press. 
Chafetz, Janet Saltzman. 1974. Masculine/feminine or human? An overview of the sociology of sex roles. Itasca: F.E. Peacock Publishers.

Charlton, Sue Ellen M. 1984. Women in third world development. Boulder: Westview Press.

Clarke, Colin. 1986. Livelihood systems, settlements and levels of living in Los Valles Centrales de Oaxaca, Mexico. Oxford: University of Oxford.

Collins, Jane L. 1991. Women and the environment. In The Women and International Development Annual, Volume 2, ed. Rita S. Gallin and Anne Ferguson. Boulder: Westview Press.

Cook, Judith A., and Mary Margaret Fonow. 1986. Knowledge and women's interests. Sociological Inquiry 56(1) Winter: 2-29.

Cook, Judith A. 1983. An interdisciplinary look at feminst methodology. Humboldt Journal of Social Relations 10: 127-152.

Cook, Scott and Martin Diskin. 1976. Markets in Oaxaca. Austin: University of Texas Press.

Crummett, M. 1987. Rural women and migration in Latin America. In Rural women and state policy, ed. Carmen Deere and Magdalena Leon. Boulder: Westview Press.

Dalton, Margarita. 1991. La mujer Oaxaquena. Oaxaca: Consejo Estatal de Poblacion de Oaxaca.

Dankleman, Irene and Joan Davidson. 1989. Women and environment in the third world. London: Earthscan Publications, Ltd.

Deere, Carmen. 1987. The Latin American agrarian reform experience. In Rural women and state policy, ed. Carmen Deere and Magdalena Leon. Boulder: Westview Press.

DeWalt, Billie R. and Kathleen M. DeWalt. 1991. The results of Mexican agriculture and food policy: Debt, drugs, and illegal aliens. In Harvest of want, ed. Scott Whiteford and Anne Ferguson. Boulder: Westview Press.

Downing, T.E. 1992. Development or destruction. Boulder: Westview Press. 
Geiger, Susan. 1992. What's so feminist about doing women's oral history? In Expanding the boundaries of women's history, ed. Cheryl Johnson-Odim and Margaret Strobel. Bloomington: Indiana University Press.

Gilbert, Alan. 1990. Latin America London: Routledge Press.

Goldrich, Daniel and David V. Carrruthers. 1992. Sustainable development in Mexico? Latin American Perspectives 72(19) Winter: 97-122.

Gonzalez, Alvaro and Marco Antonio Vasquez. 1992. Etnias, desarrollo, recursos y tecnologias en Oaxaca. Oaxaca: CIESAS.

Gorz, Andre. 1983. Ecology as politics. London: Pluto Press.

Grindle, Merilee. 1977. Bureaucrats, politicians, and peasants in Mexico. Berkeley: University of California Press.

Harding, Sandra. 1987. Feminism and methodology. Bloomington: Indiana University Press.

Jelin, Elizabeth. 1990. Women and social change in Latin America. London, UK: Zed Books, Ltd.

Kandiyoti, Deniz. 1985. Women in rural production systems: Problems and policies. Paris: United Nations Educational, Scientific and Cultural Organization.

Kaplan, Abraham. 1964. The conduct of inquiry: Methodology for behavioral science. San Francisco: Chandler Publishing Co.

King, Ynestra. 1990. Healing the wounds: Feminism, ecology, and the nature/culture dualism. In Reweaving the world: The emergence of ecofeminsm, ed. Irene Diamond and Gloria Orenstein. San Francisco: Sierra Club Books.

- 1989. The ecology of feminism and the feminism of ecology. In Healing the wounds: The promise of ecofeminism, ed. Judith Plant. Philadelphia: New Society Publishers.

- 1981. Feminism and the revolt. Heresies, no. 13: 12-16. 
Levy, Daniel and Gäbriel Szekely. 1987. Mexico: Paradoxes of stability and change. Boulder: Westview Press.

Lindsey, Linda. 1990. Gender roles. New Jersey: Prentice Hall.

Loutfi, Martha. 1985. Rural women. Geneva: International Labour Office.

Maguire, Andrew and J.W. Brown. 1986. Bordering on trouble. Resource politics in Latin America. Bethesda: Adler \& Adler Publishers, Inc.

Merchant, Carolyn. 1980. The death of nature. San Francisco: Harper \& Row.

Mies, Maria. 1983. Towards a methodology for feminist research. In Theories of women's studies, ed. G. Bowles and R. Klein. Boston: Routledge and Kegan Paul.

Morgan, David. 1981. Men, masculinity and the process of sociological enquiry. In Doing feminist research, ed. H. Roberts. London: Routledge and Kegan Paul.

Myers, Norman. 1989. Environment and Security. Foreign Policy no. 74(Spring): 23-41.

Nash, June and Helen Safa. 1985. Women and change in Latin America. South Hadley: Bergin \& Garvey Publishers, Inc.

Nebraska Feminist Collective. 1983. A feminist ethic for social science research. Women's Studies International Forum 6: 535-543.

Nuccio, Richard, Angelina Ornelas, and Ivan Restrepo. 1990. Mexico's environment and the United States. In The U.S. interest: Resources, growth, and security in the developing world, ed. Janet Welsh Brown. Boulder: Westview Press.

O'Connor, James. 1989. Uneven and combined development and ecological crisis: A theoretical model. Race and Class, 30(3): 1-11.

Oakley, Ann, and Robin Oakley. 1979. Sexism in official statistics. In Demystifying social statistics, ed. J. Irvine, I. Miles, and J. Evans. London: Pluto Press. 
Pagelow, Mildred Daley. 1979. Research on woman battering. In Stopping wife abuse, ed. J. Fleming. Garden City: Anchor Press.

Reinharz, Shulamit. 1992. Feminist methods in social research. Oxford: Oxford University Press.

- 1983. Experiential analysis. In Theories of women's studies, ed. G. Bowles and R. Klein. London: Routledge and Kegan Paul.

Rodda, Annabel. 1991. Women and the environment. London, UK: Zed Books, Ltd.

San Jose Mercury News. 1993. Mexico's population placed at 87 million. 11 November, 14A.

Shiva, Vandana. 1988. Staying alive: Women, ecology, and survival. London: Zed Books.

Smith, Dorothy E. 1979. A Sociology for Women. In The prism of sex, ed. J.A. Sherman and E.T. Beck. Madison: University of Wisconsin Press.

Sontheimer, Sally. 1991 Women and the environment: A reader. New York: Monthly Review Press.

Stephen, Lynne. 1992. Women in Mexico's popular movements. Latin American Perspectives 72(19) Winter: 73-96.

1991. Zapotec women. Austin: University of Texas Press.

Tomm, Winnie. 1989. The effects of feminist approaches on research methodologies. Ontario: Wilfrid Laurier University Press.

United Nations Department of International Economic and Social Affairs. 1986. World survey on the role of women in development. New York: United Nations Publication.

United States Department of Commerce. 1985. Women of the world. Washington D.C.: Government Printing Office.

Vickers, Jeanne. 1991. Women and the world economic crisis. London: Zed Books Ltd. 
Welsh, Brian W.W., and Pavel Butorin. 1990. Dictionary of development. New York: Garland Publishers.

Westkott, Marcia. 1983. Women's studies as a strategy for change. In Theories of women's studies, ed. G. Bowles and R. Klein. Boston: Routledge and Kegan Paul.

Whiteford, Scott \& A.E. Ferguson. 1991. Harvest of want. Boulder: Westview Press.

Wignaraja, Ponna. 1990. Women, poverty and resources. New Dehli: Sage Publications.

Wright, Angus. 1992. The death of Ramon Gonzales. Austin: The University of Texas Press.

Young, Kate. 1988. Women and economic development. Oxford: Berg Publishers Limited.

Zimmerman, Michael. 1987. Feminism, deep ecology, and environmental ethics. Environmental Ethics 9 (Spring): 21-44. 